
at the Chemical Plant Area of the Weldon Spring Site

Environmental Assessment and Information Sciences Division Argonne National Laboratory

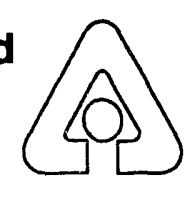

Operated by T. ie University of Chicago, under Contract W-31-109-Eng-38, for the United States Department of Energy 


\section{Argonne National Laboratory}

Argonne National Laboratory, with facilities in the states of Illinois and Idaho, is owned by the United States govermment, and operated by the University of Chicago under the provisions of a contract with the Department of Energy.

This technical memo is a product of Argonne's Environmental Assessment and Information Sciences (EAIS) Division. For information on the division's scientific and engineering activities, contact:

Director, Environmental Assessment and Information Sciences Division

Argonne National Laboratory Argonne, Illinois 60439-4815

Telophone (708) 252-3759

Presented in this technical memo are preliminary results of ongoing work or work that is more limited in scope and depth than that described in formal reports issued by the EAIS Division.

Reproduced directly from the best available copy.

Available to DOE and DOE contractors from the Office of Scientific and Technical Information, P.O. Box 62, Oak Ridge, TN 37831; prices available from (615) $576-8401$.

Availabie to the public from the National Technical Information Service, U.S. Department of Commerce, 5285 Port Royal Road, Springfield, VA 22161. 


\section{Biological Assessment for the Remedial Action at the Chemical Plant Area of the Weldon Spring Site}

by I. Hlohowskyj and C.P. Dunn

Environmental Assessment and Information Sciences Division,

Argonne National Laboratory, 9700 South Cass Avenue, Argonne, Illinois 60439

November 1992

Work sponsored by United States Department of Energy, Weldon Spring Site Remedial Action Project 


\section{CONTENTS}

NOTATION,$\ldots \ldots \ldots \ldots \ldots \ldots \ldots \ldots \ldots \ldots \ldots \ldots \ldots \ldots \ldots \ldots \ldots \ldots \ldots \ldots \ldots$

ABSTRACT $\ldots \ldots \ldots \ldots \ldots \ldots \ldots \ldots \ldots \ldots \ldots \ldots \ldots \ldots \ldots \ldots \ldots \ldots \ldots$

1 INTRODUCTION $\ldots \ldots \ldots \ldots \ldots \ldots \ldots \ldots \ldots \ldots \ldots \ldots \ldots \ldots \ldots$

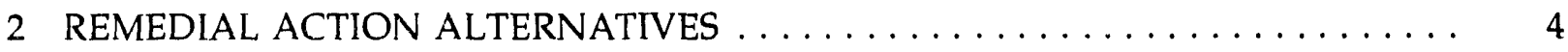

2.1 Alternative 1: No Action ....................... 9

2.2 Alternative 6a: Removal, Chemical Stabilization/Solidification, and Disposal On-Site ......................... 9

2.3 Alternative 7a: Removal, Vitrification, and Disposal On-Site . . . . . . . 12

2.4 Alternative $7 \mathrm{~b}$ : Removal, Vitrification, and Disposal at the Envirocare Facility ....................... 16

2.5 Alternative 7c: Removal, Vitrification, and Disposal

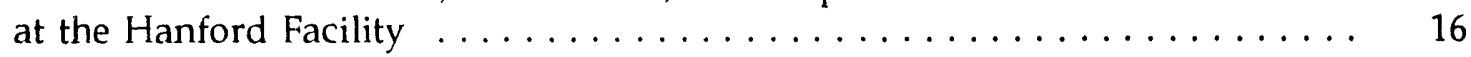

3 AFFECTED ENVIRONMENT $\ldots \ldots \ldots \ldots \ldots \ldots \ldots \ldots \ldots \ldots \ldots$

3.1 Weldon Spring Site $\ldots \ldots \ldots \ldots \ldots \ldots \ldots \ldots \ldots \ldots \ldots \ldots \ldots \ldots$

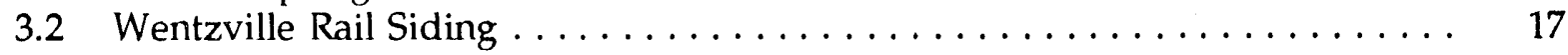

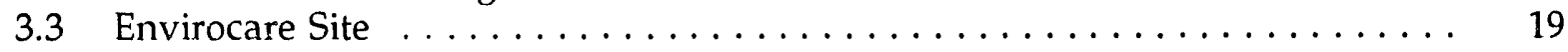

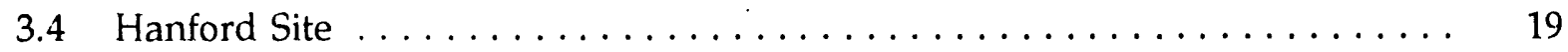

4 THREATENED AND ENDANGERED SPECIES $\ldots \ldots \ldots \ldots \ldots \ldots \ldots \ldots \ldots$

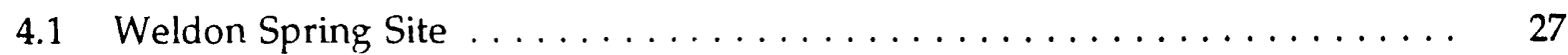

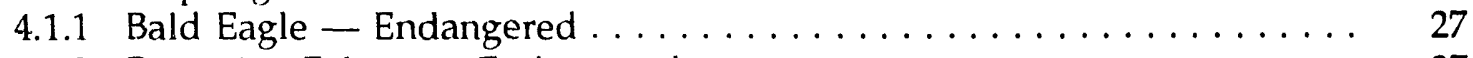

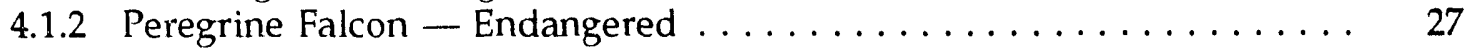

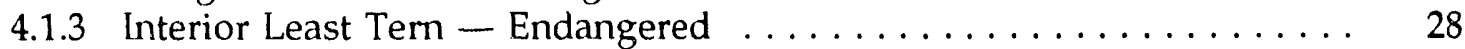

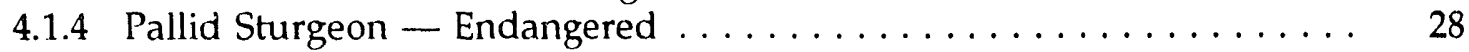

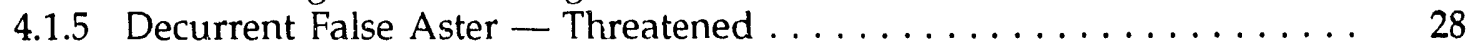

4.2 Wentzville Rail Siding . . . . . . . . . . . . . . . . . . . . . . . . . . . . 29

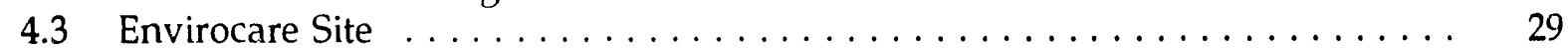

4.3.1 Bald Eagle - Endangered . . . . . . . . . . . . . . . . . 29

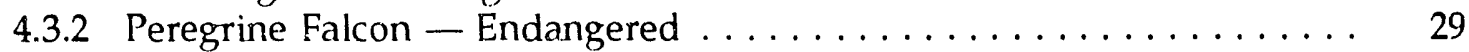

4.4 Hanford Site . . . . . . . . . . . . . . . . . . . . . . . . . . 29

4.4.1 Bald Eagle - Threatened . . . . . . . . . . . . . . . 29

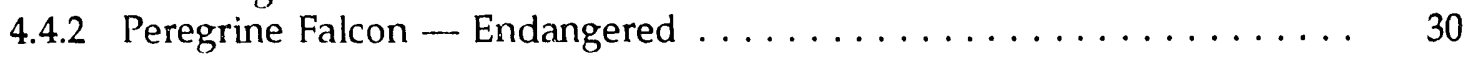

5 CANDIDATE SPECIES OR SPECIES UNDER STATUS REVIEW $\ldots \ldots \ldots \ldots \ldots$

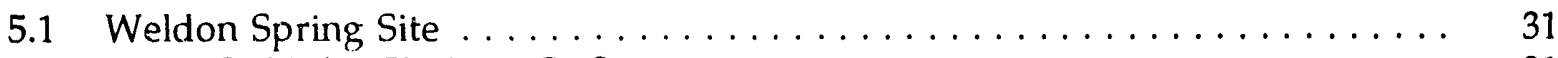

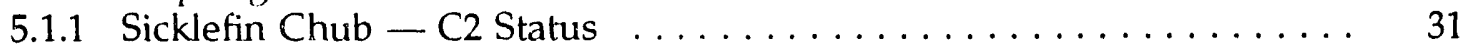

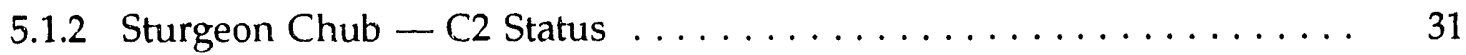

5.1 .3 Alligator Snapping Turtle - C2 Status ............... 32

5.1 .4 Eastern Massasauga $-\mathrm{C} 2$ Status . . . . . . . . . . . . . 32 


\section{CONTENTS (Cont.)}

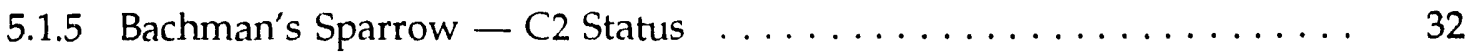

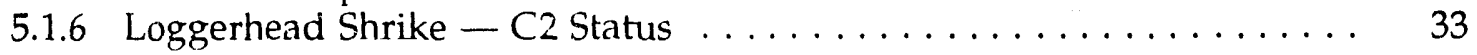

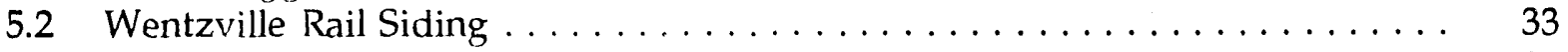

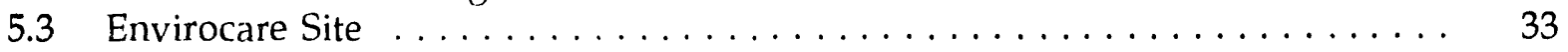

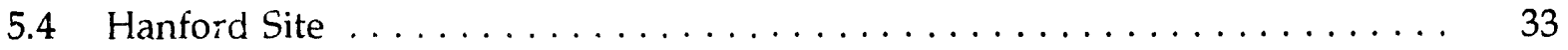

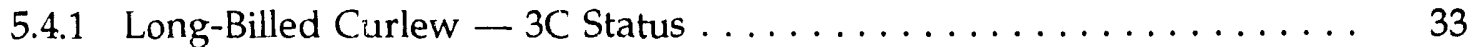

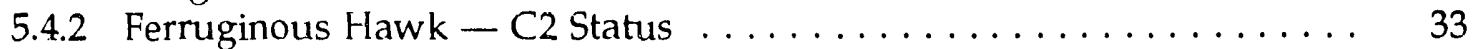

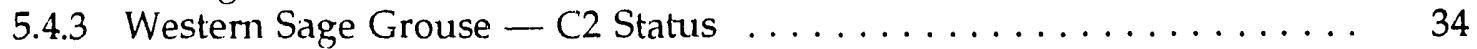

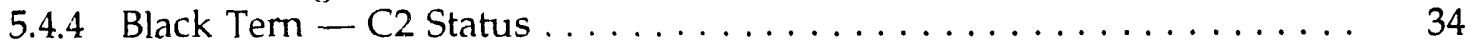

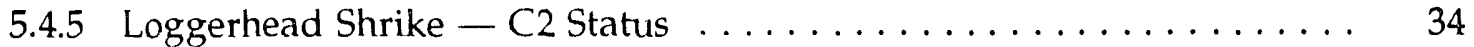

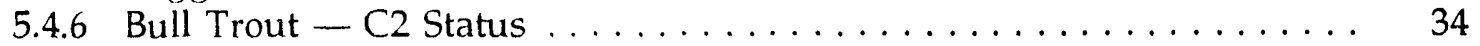

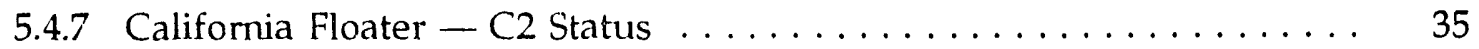

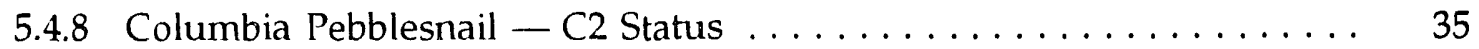

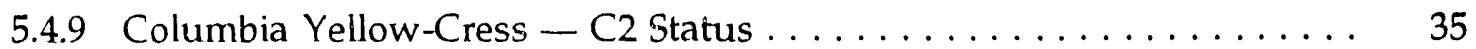

6 EFFECTS OF PROPOSED ACTION AND ALTERNATIVES ON SPECIES

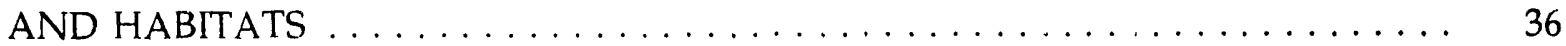

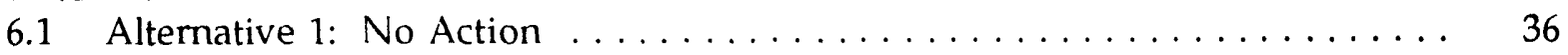

6.2 Alternative 6a: Removal, Chemical Stabilization/Solidification,

and Disposal On-Site . . . . . . . . . . . . . . . . . . 37

6.3 Alternative 7a: Removal, Vitrification, and Disposal On-Site . . . . . . . . . 40

6.4 Alternative $7 \mathrm{~b}$ : Removal, Vitrification, and Disposal

6.5 Alternative 7c: Removal, Vitrification, and Disposal at the Hanford Facility $\ldots \ldots \ldots \ldots \ldots \ldots \ldots \ldots \ldots \ldots \ldots$

7 MITIGATION AND MONITORING $\ldots \ldots \ldots \ldots \ldots \ldots \ldots \ldots \ldots \ldots$

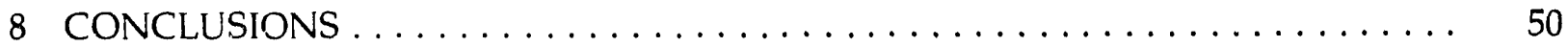

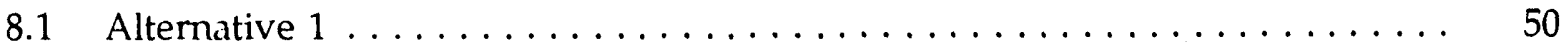

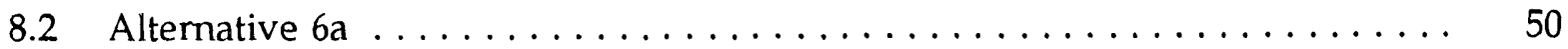

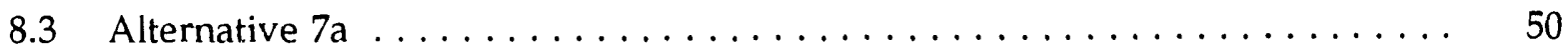

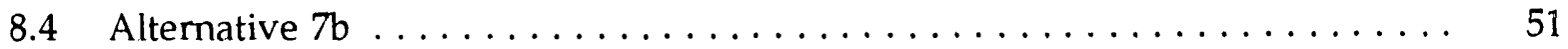

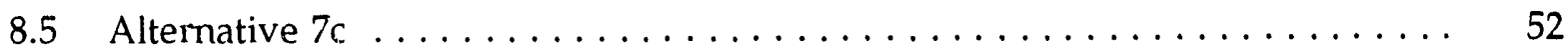

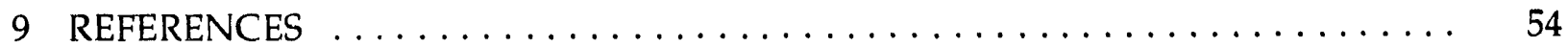

FIGURES

1 Location of the Weldon Spring Site $\ldots \ldots \ldots \ldots \ldots \ldots \ldots \ldots \ldots \ldots \ldots \ldots \ldots$

2 Location of Contaminated Vicinity Properties in the Area

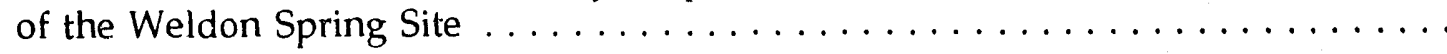




\section{FIGURES (Cont.)}

3 Location of Potential Borrow Area $\ldots \ldots \ldots \ldots \ldots \ldots \ldots \ldots \ldots \ldots$

4 Conceptual Layout of the Combination Disposal Cell

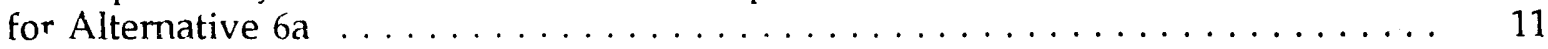

5 Conceptual Layout of the Vitrification Cell and Combination Cell

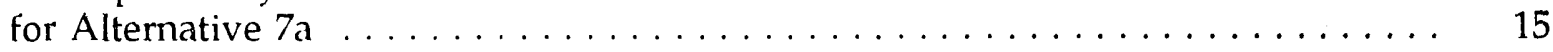

6 Terrestrial and Aquatic Habitats at the Weldon Spring Site $\ldots \ldots \ldots \ldots$

7 Location of the Envirocare Site near Clive, $U$ tah $\ldots \ldots \ldots \ldots \ldots \ldots$

8 Operationa: Areas within the Envirocare Site $\ldots \ldots \ldots \ldots \ldots \ldots \ldots \ldots \ldots \ldots$

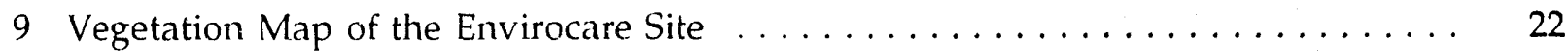

10 DOE Operational Areas within the Hanford Site . . . . . . . . . . . . . . 24

11 National and State Wildlife Refuges in the Vicinity

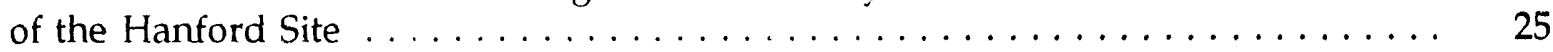

12 Distribution of Vegetation Types on the Hanford Site $\ldots \ldots \ldots \ldots \ldots$

\section{TABLES}

1 Contaminants of Concern for the Weldon Spring Site $\ldots \ldots \ldots \ldots \ldots \ldots$

2 Estimated Areas and Volumes of Contaminated Media . . . . . . . . . . . 6

3 Fate of Contaminants during Vitrification $\ldots \ldots \ldots \ldots \ldots \ldots \ldots$

4 Estimated Leachate Concentrations for Chemically Stabilized/ Solidified Sludge and Quarry Soil . . . . . . . . . . . . . . . . . . . . 39

5 Expected Leachate Concentrations for Vitrified Sludge and Site Soil . . . . . . . . 41

6 Major Monitoring and Mitigative Measures for the Action Alternatives . . . . . 47 


\section{NOTATION}

The following is a list of the acronyms, initialisms, and abbreviations (including units of measure) used in this document. Acronyms used in tables only are defined in the respective tables.

\section{ACRONYMS, INITIALISMS, AND ABBREVIATIONS}

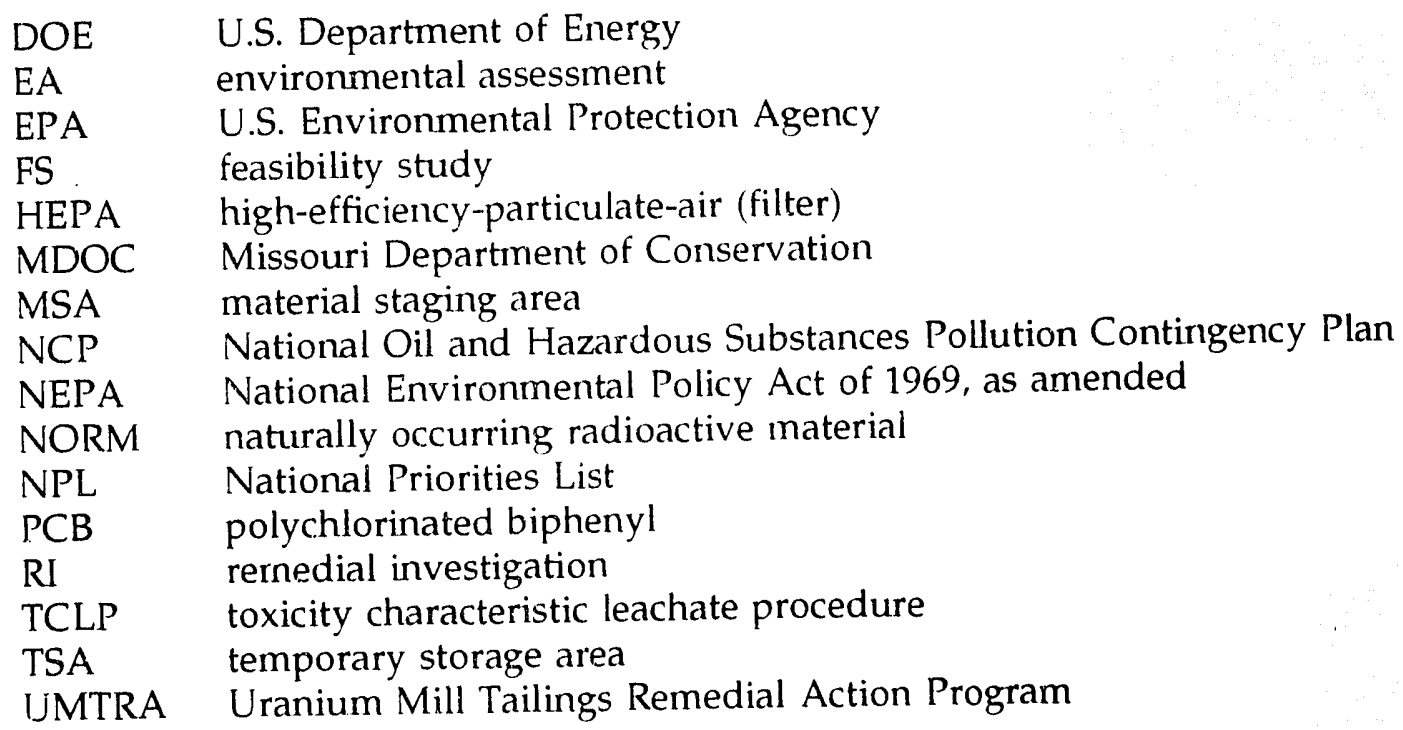

IJNITS OF MEASURE

$\begin{array}{llll}\mathrm{cm} & \text { centimeter } & \mathrm{lb} & \text { pound } \\ \mathrm{d} & \text { day } & \mathrm{m} & \text { meter } \\ \mathrm{ft} & \text { foot } & \mathrm{m}^{2} & \text { square meter } \\ \mathrm{ft}^{2} & \text { square foot } & \mathrm{m}^{3} & \text { cubic meter } \\ \mathrm{ha} & \text { hectare } & \mathrm{mg} & \text { milligram } \\ \mathrm{in} . & \text { inch } & \mathrm{mi} & \text { mile } \\ \mathrm{kg} & \text { kilogram } & \mathrm{mi} & \text { square mile } \\ \mathrm{km} & \text { kilometer } & \mathrm{pCi} & \text { picocurie } \\ \mathrm{km} & \text { square kilometer } & \mathrm{rad} & \text { radiation absorbed dose } \\ \mathrm{L} & \text { liter } & \mathrm{yd}^{3} & \text { cubic yard }\end{array}$




\title{
BIOLOGICAL ASSESSMENT FOR THE REMEDIAL ACTION AT THE CHEMICAL PLANT AREA OF THE WELDON SPRING SITE
}

by

\author{
I. Hlohowskyj and C.P. Dunn
}

\begin{abstract}
The Weldon Spring site in St. Charles County, Missouri, became contaminated during the 1940s through the 1960s as a result of explosives production by the U.S. Army and uranium and thorium processing by the predecessor agency of the U.S. Department of Energy (DOE). The site is listed on the National Priorities List of the U.S. Environmental Protection Agency, and DOE is responsible for its cleanup. Contaminants are present in soil, surface water, and aquatic sediments. Alternatives identified for site remediation are no action (included as a baseline for comparison), treatment and disposal of the wastes at the Weldon Spring site, and on-site treatment followed by off-site disposal at either a commercial facility near Clive, Utah, or at DOE's Hanford site near Richland, Washington. In accordance with the requirements of the Endangered Species Act, this biological assessment has been prepared to evaluate the potential effects of proposed remedial action alternatives on federal listed (endangered or threatened) and candidate species at the respective sites. The assessment includes consideration of the environmental setting at each site; the federal listed and candidate species that could occur at each site; the construction, excavation, and treatment activities under each alternative; and the amount of land area affected at each site. On the basis of these considerations, no adverse impacts to federal listed species are expected to result from any of the action alternatives. The Bachman's sparrow and the loggerhead shrike, both federal candidate species, might incur adverse impacts due to habitat loss resulting from excavation at the potential off-site borrow area, depending on the area selected during the detailed design phase of this action. The loggerhead shrike could also be adversely impacted by habitat loss during disposal cell construction at the Hanford site. If no action were taken to remediate the Weldon Spring site, federal listed and candidate species might be exposed to contaminants directly or as a result of offsite transport or food chain transfer.
\end{abstract}

\section{INTRODUCTION}

The U.S. Department of Energy (DOE) is responsible for cleanup activities at the Weldon Spring site under its Environmental Restoration and Waste Management: Program. A major goal 


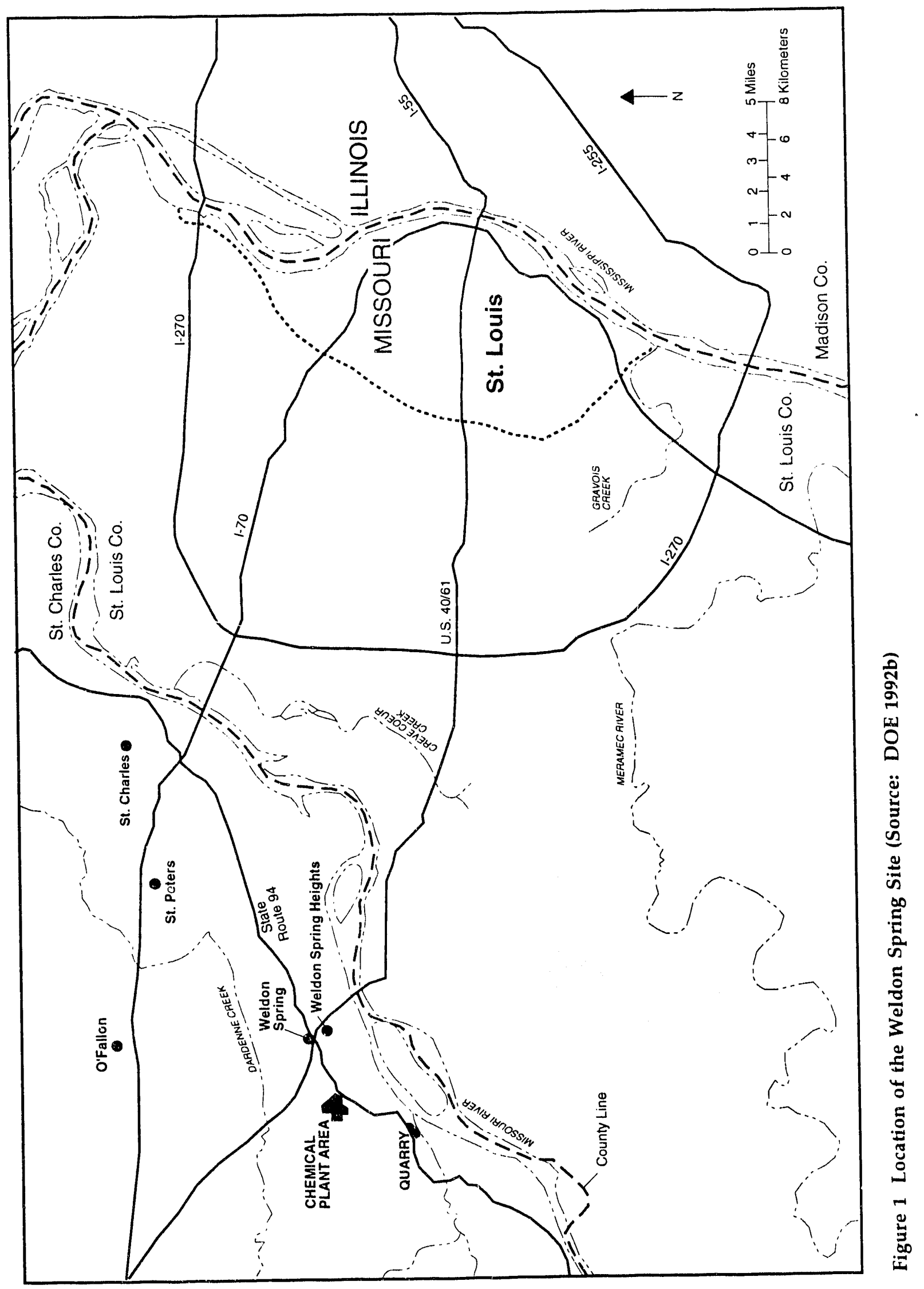


of this program is to eliminate potential hazards to human health and the environment. The Weldon Spring site is located in St. Charles County, Missouri, approximately $48 \mathrm{~km}$ (30 mi) west of St. Louis (Figure 1). The site consists of two noncontiguous areas: a chemical plant area and a limestone quarry, which became radioactively and chemically contaminated as a result of processing and disposal activities that occurred from the 1940s through the 1960s. In addition to these areas, a number of off-site locations are chemically and/or radioactively contaminated as a result of past processing activities at the chemical plant. The Weldon Spring site is currently listed on the National Priorities List (NPL) of the U.S. Environmental Protection Agency (EPA).

Explosives were produced at the chemical plant during the 1940s, and uranium and thorium materials were processed during the 1950s and 1960s. Waste slurries generated at the chemical plant area during the latter operational period were piped to four man-made retention ponds, referred to as raffinate pits; various solid wastes (i.e., process residues and decontamination material including soil, rubble, metal debris, and equipment) were disposed of in the quarry between 1942 and 1969. Remedial activities have already begun at the quarry; the most significant activity to be conducted over the next several years is the excavation and transport of contaminated solid material to the chemical plant area for short-term storage pending a decision for disposal of all wastes resulting from remedial action at the Weldon Spring site.

Cleanup of the Weldon Spring site could entail the excavation, treatment, and disposal of approximately $519,000 \mathrm{~m}^{3}\left(679,000 \mathrm{yd}^{3}\right)$ of contaminated sludge, sediment, and soil from a number of on-site and off-site locations. Alternatives being considered for treatment of the more highly contaminated material include chemical stabilization/solidification and vitrification. Alternatives being evaluated for disposal of the contaminated media include the construction of a disposal cell at (1) the chemical plant area of the Weldon Spring site, (2) the Envirocare of Utah, Inc., commercial facility near Clive, Utah, or (3) the 200-West Area at the DOE Hanford facility near Richland, Washington.

Construction and/or backfill activities associated with the different alternatives are estimated to require up to about 1.16 million $\mathrm{m}^{3}$ (1.52 million $\left.\mathrm{yd}^{3}\right)$ of clean, uncontaminated borrow (fill) material. Of this amount, DOE might obtain up to $895,000 \mathrm{~m}^{3}$ (1.17 million $\left.\mathrm{d}^{3}\right)$ from a nearby source, potentially from a 61-ha (150-acre) parcel of land located in the Weldon Spring Wildlife Area about $1.9 \mathrm{~km}(1.2 \mathrm{mi})$ east of the chemical plant area. The remaining $267,000 \mathrm{~m}^{3}\left(349,000 \mathrm{yd}^{3}\right)$ of borrow material would be obtained from existing commercial sources. In the event that off-site disposal is selected, a dedicated rail siding could be constructed near the town of Wentzville, Missouri, from which treated and untreated containerized material would be shipped by rail to the disposal cell location.

Removal, treatment, and disposal of the contaminated sediment, sludge, and soil at the Weldon Spring site are necessary to eliminate potential hazards to human health and the environment and to complete overall site remediation. Potential environmental impacts of remedial action alternatives for the chemical plant area are evaluated in the feasibility study (FS) (DOE 1992b) for the chemical plant area. This biological assessment evaluates the potential for the remedial action alternatives to adversely affect listed and proposed threatened and endangered species and their designated critical habitats. 


\section{REMEDIAL ACTION ALTERNATIVES}

Radioactive and chemical contaminants are present in a number of on-site and off-site areas. The primary radioactive contaminants are uranium, thorium, and radium. Chemical contaminants include metals, inorganic ions, and nitroaromatic compounds. Contaminants of concern for the site are given in Table 1. Contaminated media include surface water, groundwater, sediment, and soil. The purpose of the planned remedial action at the chemical plant area is to reduce potential hazards to human health and the environment, and to make surplus real property available for other uses to the extent possible. Preliminary estimates of the acreage that would be disturbed and the volumes of contaminated materials associated $w$ ith the site are given in Table 2.

Alternative remedial actions were developed by identifying remedial technologies and process options potentially applicable to the contaminated media at the site. The technologies considered included those identified in the National Oil and Hazardous Substances Pollution Contingency Plan (NCP) (EPA 1990). These technologies and process options were evaluated in accordance with the NCP and EPA guidance (EPA 1988). On the basis of this evaluation, various control technologies were identified as potential components of remedial action alternatives for the site. These technologies were incorporated into seven preliminary alternatives:

Alternative 1: No Action;

Alternative 2: In-Situ Containment and Limited Disposal;

Alternative 3: In-Situ Chemical Stabilization/Solidification and Limited Disposal;

Alternative 4: In-Situ Vitrification and Limited Disposal;

Alternative 5: Removal, Minimal Treatment, and Disposal;

Alternative 6: Removal, Chemical Stabilization/Solidification, and Disposal; and

Alternative 7: Removal, Vitrification, and Disposal.

All of the action alternatives (Alternatives 2 through 7) were further divided into alternative disposal options: disposal in an on-site engineered disposal cell (Alternatives 2a, 3a, 4a, 5a, 6a, and 7a); disposal off-site at the Envirocare facility near Clive, Utah (Alternatives $2 b, 3 b, 4 b, 5 b$, $6 b$, and $7 b$ ); disposal off-site at the DOE Hanford facility near Richland, Washington (Alternatives $2 c, 3 c, 4 c, 5 c, 6 c$, and $7 c$ ); and disposal off-site at a hypothetical nearby facility (Alternatives $2 \mathrm{~d}, 3 \mathrm{~d}, 4 \mathrm{~d}, 5 \mathrm{~d}, 6 \mathrm{~d}$, and $7 \mathrm{~d}$ ). 
TABLE 1 Contaminants of Concern for the Weldon Spring Site ${ }^{a}$

\begin{tabular}{|c|c|c|c|c|}
\hline Radionuclides $^{b, c}$ & Metals & $\begin{array}{c}\text { Other } \\
\text { Inorganic } \\
\text { Compounds }\end{array}$ & $\begin{array}{l}\text { Nitroaromatic } \\
\text { Compounds }\end{array}$ & PCBs and PAHs \\
\hline $\begin{array}{l}\text { Actinium-227 } \\
\text { Lead-210 } \\
\text { Protactinium- } \\
231 \\
\text { Radium-226 } \\
\text { Radium-228 } \\
\text { Radon-220 } \\
\text { Radon-222 } \\
\text { Thorium-230 } \\
\text { Thorium-232 } \\
\text { Uranium-235 } \\
\text { Uranium-238 }\end{array}$ & $\begin{array}{l}\text { Aluminum }^{\mathrm{d}} \\
\text { Antimony } \\
\text { Arsenic }^{\mathrm{b}} \\
\text { Barium } \\
\text { Beryllium }^{\mathrm{b}} \\
\text { Cadmium }^{\mathrm{b}} \\
\text { Chromium }^{\mathrm{b}} \\
\text { Cobalt } \\
\text { Copper } \\
\text { Lead }^{\mathrm{b}} \\
\text { Lithium }_{\text {Manganese }} \\
\text { Mercury } \\
\text { Molybdenum } \\
\text { Nickel } \\
\text { Selenium } \\
\text { Silver } \\
\text { Thallium } \\
\text { Uranium } \\
\text { Vanadium } \\
\text { Zinc }\end{array}$ & $\begin{array}{l}\text { Asbestos } \\
\text { Fluoride } \\
\text { Nitrate } \\
\text { Nitrite }\end{array}$ & $\begin{array}{l}\text { DNB } \\
2,4-D N T^{b} \\
2,6-D N T^{b} \\
\text { NB } \\
\text { TNB } \\
\text { TNT }^{b}\end{array}$ & $\begin{array}{l}\text { PCBs }^{b} \\
\text { Acenaphthene } \\
\text { Anthracene } \\
\text { Benz(a)anthracene }^{b} \\
\text { Benzo(b)fluoranthene } e^{b} \\
\text { Benzo(k)fluoranthene }{ }^{b} \\
\text { Benzo(g,h,i)perylene } \\
\text { Benzo(a)pyrene }{ }^{b} \\
\text { Chrysene } \\
\text { Fluoranthene } \\
\text { Fluorene } \\
\text { Indeno(1,2,3-cd)pyrene }{ }^{b} \\
\text { 2-Methyinaphthalene } \\
\text { Naphthalene } \\
\text { Phenanthrene } \\
\text { Pyrene }\end{array}$ \\
\hline
\end{tabular}

a Notation: $\mathrm{DNB}=1,3$-dinitrobenzene; $2,4-\mathrm{DNT}=2,4$-dinitrotoluene; 2,6 -DNT $=2,6$-dini. trotoluene; $\mathrm{NB}=$ nitrobenzene; $\mathrm{TNB}=1,3,5$-trinitrobenzene; $\mathrm{TNT}=$ trinitrotoluene, $\mathrm{PCBs}=$ polychlorinated biphenyls.

b Potential carcinogen.

c Exposure to gamma radiation resulting from the presence of these radionuclides was also evaluated.

d A contaminant of concern only for the ecological risk assessment.

These preliminary alternatives were evaluated for applicability to remediating the Weldon Spring site on the basis of three general criteria: effectiveness, implementability, and cost (DOE 1992b). The effectiveness of each alternative was determined by its overall ability to protect human health and the environment in both the short term and long term. The implementability of each alternative was determined by its technical feasibility, resource availability, and administrative feasibility. Relative costs were evaluated at the screening stage by comparing general estimates for each alternative. 
TABLE 2 Estimated Areas and Volumes of Contaminated Media

\begin{tabular}{|c|c|c|}
\hline Medium & $\begin{array}{c}\text { Area } \\
\text { (acres) }\end{array}$ & $\begin{array}{l}\text { Volume } \\
\left(\mathrm{yd}^{3}\right)\end{array}$ \\
\hline \multicolumn{3}{|l|}{ Sludge } \\
\hline Raffinate pits & 25.8 & 220,000 \\
\hline \multicolumn{3}{|l|}{ Sediment } \\
\hline On-site & 11.5 & 19,300 \\
\hline Cff-site & 116.5 & 100,500 \\
\hline \multicolumn{3}{|l|}{ Soil } \\
\hline On-site & 58.4 & 335,400 \\
\hline Off-site & 1.2 & 3,600 \\
\hline \multicolumn{3}{|l|}{ Structural material } \\
\hline Concrete rubble & 4.8 & 89,200 \\
\hline Steel & 3.3 & 61,900 \\
\hline Debris & 0.5 & 3,700 \\
\hline Asbestos & 0.5 & 8,800 \\
\hline Building 434 & 0.5 & 5,000 \\
\hline Process chemicals & 1.0 & 3,960 \\
\hline \multicolumn{3}{|l|}{ Vegetation } \\
\hline From quarry & 0.4 & 6,500 \\
\hline From building demolition & 0.1 & 750 \\
\hline From sitewide areas & 3.8 & 23,400 \\
\hline
\end{tabular}

On the basis of the screening analysis for the preliminary alternatives (DOE 1992b), five alternatives were retained for detailed evaluation:

Alternative 1: No action;

Alternative 6a: Removal, Chemical Stabilization/Solidification, and Disposal On-Site;

Alternative 7a: Removal, Vitrification, and Disposal On-Site;

Alternative $7 \mathrm{~b}$ : Removal, Vitrification, and Disposal at the Envirocare Facility near Clive, Utah; and

Alternative 7c: Removal, Vitrification, and Disposal at the Hanford Facility near Richland, Washington.

Under all but the no-action alternative, contaminated materials (Table 2) would be removed from various source areas, treated as appropriate, and then disposed of in an engineered cell either on-site or off-site. 
The alternatives addressed in this biological assessment (and in the FS for remedial action at the chemical plant area) incorporate consideration of the impacts from remedial actions that are currently planned or being developed for most of the contaminated source areas at the Weldon Spring site. This assessm nt does not, however, address all impacts associated with certain locations whose cleanup is cutside the scope of the current decision-making process (i.e., the Southeast Drainage; Femme Osage Slough and vicinity property B9; and Lakes 34, 35, and 36). Those areas are being considered at this stage of the process only with regard to (1) the estimated volume of contaminated media that might be removed from each area under a future action and (2) the disposal cell requirements needed to handle the removed material. They are evaluated for potential impacts to listed and proposed species from the no-action alternative (i.e., in the absence of remedial action).

The Southeast Drainage, an intermittent stream located southeast of the site in the Weldon Spring Wild life Area (Figure 2), contains contaminated sediment, soil, and surface water. Contaminants include radionuclides, inorganic ions, and nitroaromatic compounds. Femm: Osage Slough is a small portion of Femme Osage Creek that was cut off from its original channei by a levee constructed in 1959 and 1960. The slough, located in the Weldon Spring Wildlife Area south of the Weldon Spring quarry, contains radioactively and chemically contaminated surface water and sediment. Vicinity property B9 is located adjacent to the slough (Figure 2) and contains contaminated soil. Contaminated surface water, sediment, and soil are also present in prortions of Lakes 34, 35, and 36 in the August A. Busch Memorial Wildlife Area.

The Southeast Drainage is being treated as a separate response action, in part because additional characterization is needed for the drainage and also because conditions in the drainage will change as a resuli of cleanup activities at the chemical plant area. The drainage will be addressed as a separate removal action within the next several years, and environmental documentation will be prepared to support related decisions.

Lakes 34, 35, and 36 will be addressed in conjunction with the Missouri Department of Conservation (MDOC) sedimentation management activities scheduled for these lakes (Dieffenbach 1992). The sedimentation management program addresses the problem of reservoir siltation and also provides for maintenance of the reservoir dams. In this program, a lake targeted for renovation is drained and the accumulated sediments are excavated. The lake is then refilled and restocked with fish. To remediate Lakes 34, 35, 36, DOE will remove contaminated sediment and sho:eline soil after the MDOC has drained the lakes. Following removal of the contaminated sediment and soil by DOE, the MDOC will complete sediment removal, refill the lakes, and restore the habitats and biota. A biological assessment may be prepared in the future when the MDOC begins its renovation activities at Lakes 34, 35, and 36. The impacts associated with DOE's removal of the contaminated sediment and soil from these lakes are expected to be identical to the impacts that would be incurred during the scheduled MDOC sediment removal lake renovation activities alone. Because the contaminated areas are only part of the entire area that would be drained and excavated by the MDOC, impacts would be bounded by those associated with the MDOC activities. The overall purpose of these activities is to improve conditions at these lakes. 


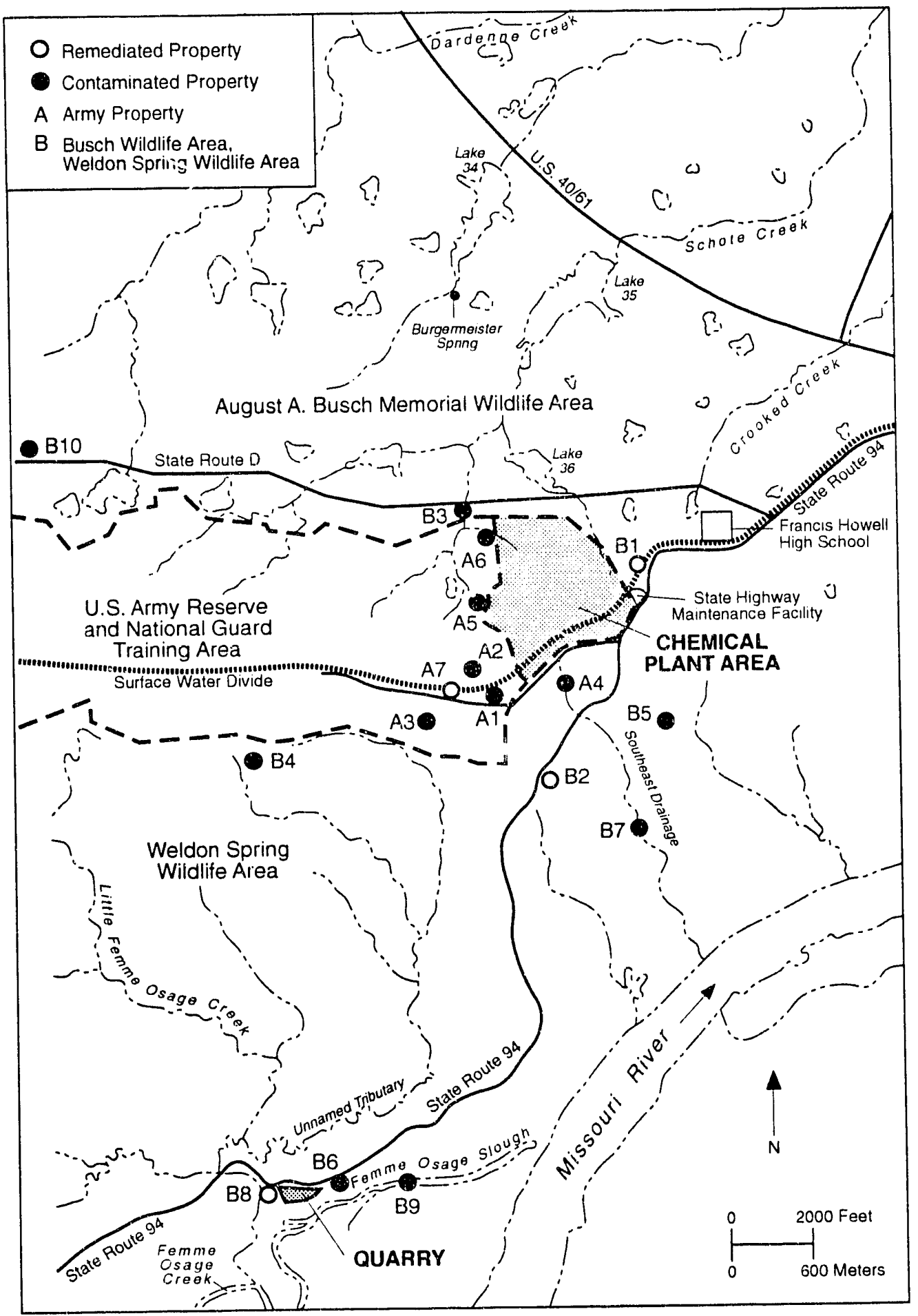

FIGURE 2 Location of Contaminated Vicinity Properties in the Area of the Weldon Spring Site (Source: DOE 1992b) 
The Femme Osage Slough and vicinity property B9 (Figure 2) will be addressed during the follow-on decision-making process for the final cleanup of the quarry (quarry residuals operable unit). A remedial investigation/feasibility study (RI/FS) work plan is being prepared for these areas, and a biological assessment will be included with the planned RI/FS. This document package will incorporate values of the National Environmental Policy Act (NEPA) and will be consistent with the level of analysis for an environmental assessment (EA).

A source of borrow soil is needed to support backfill and construction activities planned for the current stage of site cleanup. A potential location for much of this material $\left(895,000 \mathrm{~m}^{3}\right.$ [1.17 million $\left.\mathrm{yd}^{3}\right]$ ) has been identified (Figure 3 ) and evaluated as the representative borrow area for the analyses in the FS. In the event that the proposed borrow area is selected as the source of clean fill for use at the chemical plant area, an EA would be prepared to address potential impacts from excavation and other activities. Potential impacts from activities at the proposed borrow area to listed, candidate, and Category 2 (C2) species would be evaluated in a biological assessment included in the EA.

\subsection{AI.TERNATIVE 1: NO ACTION}

No action is included as an alternative in the FS to provide a baseline for comparison with the other alternatives. Under this alternative, no further remedial action would be taken at the site. Siveral interim response actions for which decisions have been finalized are assumed to be in effect as the baseline condition for the site:

- The bulk waste excavated from the quarry is assumed to be in storage on-site in the temporary storage area (TSA).

- The water treatment plants at the quarry and the chemical plant area are assumed to be operational.

- Other than the converted storage building (Building 434), the chemical plant buildings and other structures are assumed to be dismantled and in storage on-site within the material staging area (MSA).

Activities that would continue at the site include environmental monitoring of groundwater, surface water, and air; maintenance of all on-site storage areas, dikes, fences, and remaining buildings; operation of the water treatment plants; and provision of site security.

\subsection{ALTERNATIVE 6a: REMOVAL, CHEMICAL STABILIZATION/SOLIDIFICATION, AND DISPOSAL ON-SITE}

Under Alternative 6a, contaminated material from the on-site source areas would be removed, treated (as appropriate), and disposed of in an engineered disposal cell. Contaminated soil, sludge, and sediment would be excavated with conventional earth-moving equipment and dredges. These materials would then be treated by chemical stabilization/solidification to reduce 


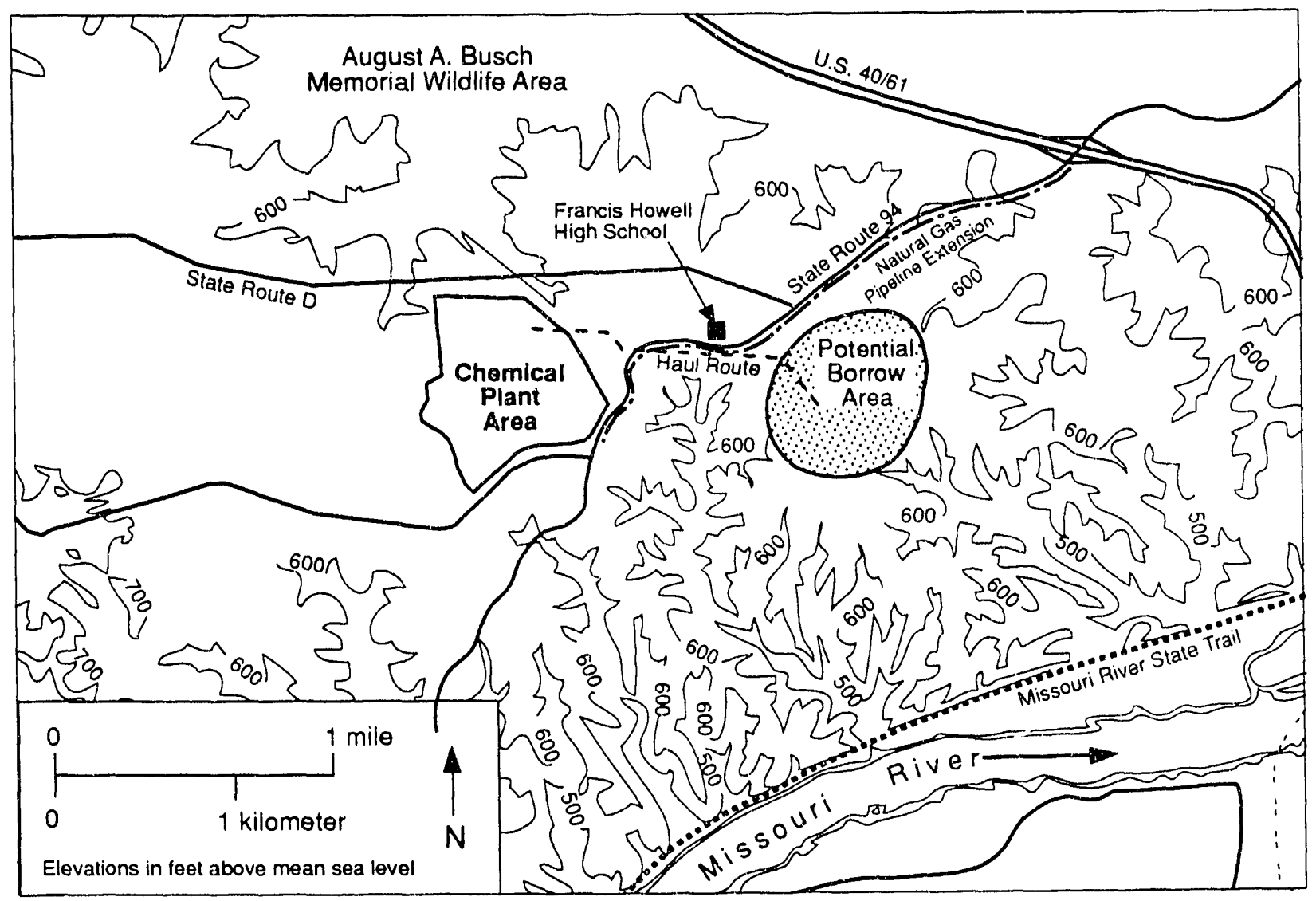

FIGURE 3 Location of Potential Borrow Area (Source: DOE 1992b)

contaminant mobility, facilitate waste handling, and eliminate free water. Soil, sludge, and sediment in storage at the TSA would also be treated, as appropriate. After treatment, the contaminated material would be placed into an on-site engineered cell. Off-site contaminated soil and sediment would be removed with conventional construction and excavation equipment and transported to the chemical plant area in covered trucks for similar treatment and/or disposal.

Chemical stabilization/solidification of the contaminated media would be accomplished by mixing the contaminated material with a reagent consisting of a blend of cement and fly ash. This treatment would occur in an engineered treatment facility built on-site that would require an area of approximately 0.40 ha (1.0 acre). A volume reduction facility, occupying an area of approximately 0.084 ha $(0.21$ acres), would also be built on-site to reduce the volume of structural material (such as metal, concrete, and glass), rock, and containerized decontamination material, which would also facilitate waste handling and disposal. Following chemical treatment or volume reduction, the contaminated material would be transported by truck to an on-site engineered disposal cell (Figure 4). 


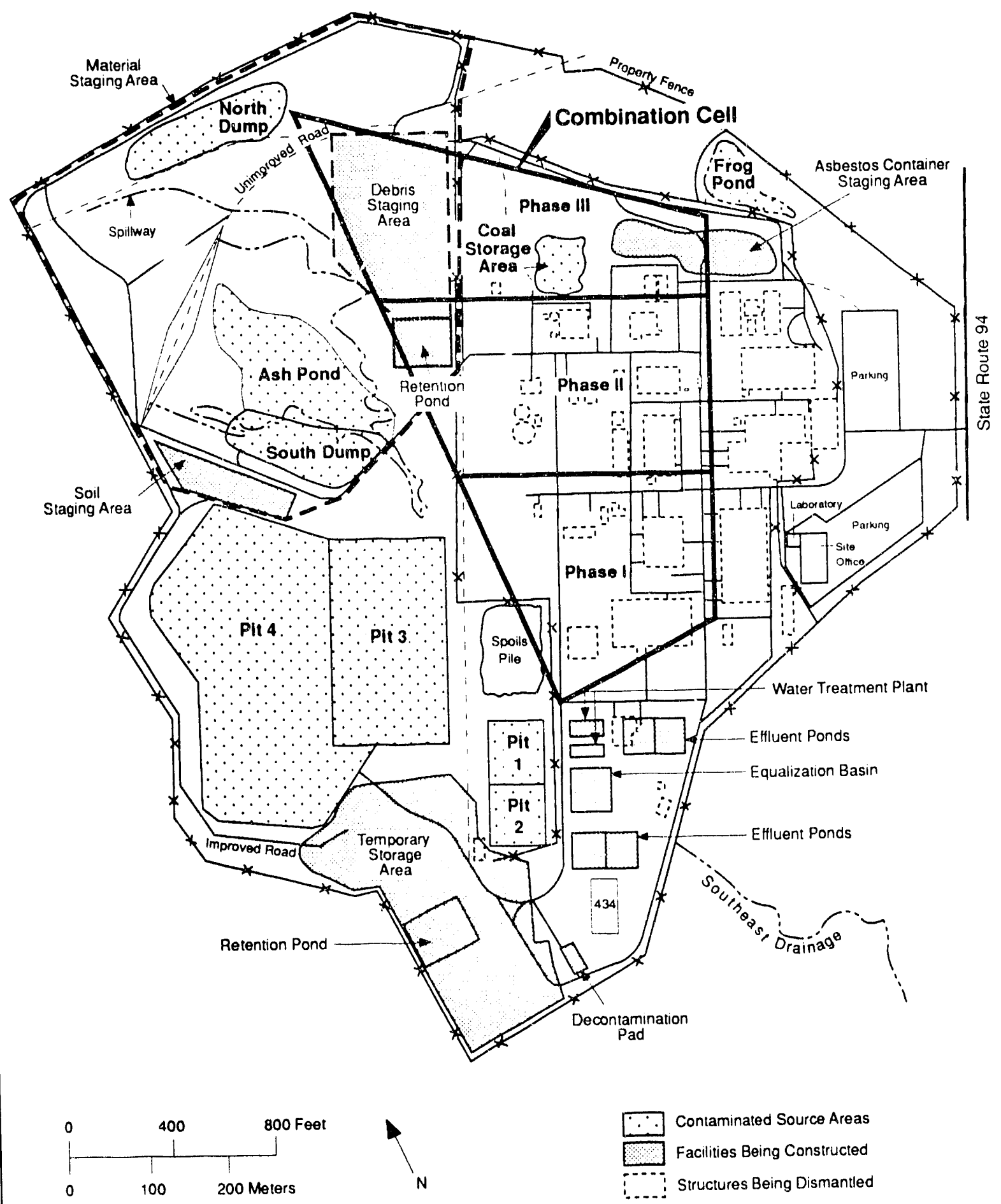

FIGURE 4 Conceptual Layout of the Combination Disposal Cell for Alternative 6a (Gource: DOE 1992b) 
The disposal cell would include a bottom composite liner (synthetic membrane and compacted clay), a leachate collection and removal system, and a multilayer cover system including an infiltration/radon attenuation barrier (DOE 1992b). The design would incorporate features used in disposal cells for radium-contaminated uranium mill tailings (such as the DOE Uranium Mill Tailings Remedial Action [UMTRA] Program disposal cell design) and solid and hazardous waste (such as the Resource Conservation and Recovery Act [RCRA] disposal cell design). This type of disposal cell is referred to as a combination cell. The cell would be located on-site and would occupy an area of about 17 ha (42 acres).

Good engineering practices and appropriate mitigative measures would be used during all excavation and construction activities to prevent or minimize potential erosion, dust emissions, and contaminant releases. Following completion of remedial action activities and closure of the treatment and storage facilities and disposal cell, the site would be graded and vegetated. Clean borrow and topsoil would be used to reclaim excavated areas (including the raffinate pits). The site would be graded to match undisturbed areas, prevent ponding, minimize erosion, and provide a transition into natural drainages in the area. Except for the disposal cell, which would be planted with grasses, the site would be seeded with hardy native vegetation, including shrubs and trees.

\subsection{ALTERNATIVE 7a: REMOVAL, VITRIFICATION, AND DISPOSAL ON-SITE}

Under Alternative 7a, contaminated sludge, soil, and sediment would be removed from the on-site and off-site source areas in the same manner as identified for Alternative 6a. In contrast to Alternative $6 a$, the contaminated material under Alternative $7 a$ would be treated by vitrification rather than chenical stabilization. Under the vitrification option, the highly contaminated soil, sludge, and stiment would be placed in an enclosed vessel and melted, then quenched with water to produce a small $(<0.64-\mathrm{cm}[<0.25-\mathrm{in}$.] diameter) fritted glass product. Organic contaminants and some inorganic contaminants would be destroyed by the high vitrification temperatures, whereas the radioactive and other inorganic contaminants would be trapped in the glass-like product. The fate of contaminants during vitrification is shown in Table 3. The lightly contaminated soil and sediment and the structural material would not be vitrified.

Two treatment facilities would be built on-site: a volume reduction facility identical to that described for Alternative 6a and a sludge processing facility ( 0.40 ha [1.0 acre]) with dewatering and vitrification systems. Contaminated sludge and sediment would be dewatered prior to vitrification, and the water removed during the dewatering process would be treated in the on-site water treatment plant. The dewatered material would then be fed to the vitrification system for treatment. An off-gas treatment system (e.g., primary and aerosol scrubbers) would be used to remove entrained dust, submicron aerosols, and noncombustible gases created during vitrification of contaminated soil, sludge, and sediment. As a final filtration step, all off gas would be passed through high-efficiency-particulate air (HEPA) filters. 
TABLE 3 Fate of Contaminants during Vitrification

\begin{tabular}{|c|c|c|c|c|c|}
\hline \multirow[b]{2}{*}{ Contaminant } & \multirow[b]{2}{*}{ Unit } & \multirow[b]{2}{*}{$\begin{array}{c}\text { Annual } \\
\text { Feed Rate }\end{array}$} & \multicolumn{3}{|c|}{ Fate of Contaminants as Percent of Feed } \\
\hline & & & $\begin{array}{c}\text { Encased in } \\
\text { Glass } \\
(\%)\end{array}$ & $\begin{array}{c}\text { Scrubber } \\
\text { Residuals } \\
(\%)\end{array}$ & $\begin{array}{c}\text { Released to } \\
\text { Atmosphere } \\
(\%)\end{array}$ \\
\hline Metals & tons & & & & \\
\hline Arsenic & & 28.3 & 77.57 & 22.43 & $5.9 \times 10^{-6}$ \\
\hline Cadmium & & 1.4 & 75.05 & 24.95 & $6.6 \times 10^{-6}$ \\
\hline Chromium & & 2.4 & 99.77 & 0.23 & $1.2 \times 10^{-8}$ \\
\hline Copper & & 18.7 & 99.77 & 0.23 & $1.2 \times 10^{-8}$ \\
\hline Lead & & 17.3 & 93.12 & 6.88 & $1.8 \times 10^{-6}$ \\
\hline Mercury & & 0.3 & () & 40.0 & 60.0 \\
\hline Nickel & & 21.4 & 99.77 & 0.23 & $1.2 \times 10^{-8}$ \\
\hline Selenium & & 2.3 & 0.06 & 99.94 & $2.6 \times 10^{-5}$ \\
\hline Vanadium & & 196 & 99.77 & 0.23 & $1.2 \times 10^{-8}$ \\
\hline Zinc & & 16.9 & 98.18 & 1.82 & $9.2 \times 10^{-8}$ \\
\hline Inorganic anions & tons & & & & \\
\hline Chloride & & 0.3 & 0.10 & 94.90 & 4.99 \\
\hline Fluoride $^{d}$ & & 2.3 & 99.77 & 0.23 & 0.0023 \\
\hline Nitrates $^{\mathrm{e}}$ & & 141 & 0 & 50.0 & 50.0 \\
\hline Nitrites ${ }^{e}$ & & 1.4 & 0 & 50.0 & 50.0 \\
\hline Sulfate $^{f}$ & & 262 & 74.07 & 23.33 & 2.59 \\
\hline Nitroaromatic compounds $g$ & tons & & & & \\
\hline 2,4-DNT & & 0.2 & $<0.10$ & $<0.10$ & 0.0001 \\
\hline $2,6-\mathrm{DNT}$ & & 0.2 & $<0.10$ & $<0.10$ & 0.0001 \\
\hline $2,4,6-\mathrm{TNT}$ & & 5.9 & $<0.10$ & $<0.10$ & 0.0001 \\
\hline Gther & tons & & & & \\
\hline Organic nitro groups & & 1.3 & 0 & 50.0 & 50.0 \\
\hline Thermal $\mathrm{NO}_{\mathrm{x}} \mathrm{h}^{\mathrm{O}}$ & & 274 & 0 & 95.30 & 4.7 \\
\hline Total nonvolatile solids & & 45,600 & 99.77 & 0.23 & $1.2 \times 10^{-8}$ \\
\hline Radionuclides $^{\mathrm{i}}$ & $\mathrm{Ci}$ & & & & \\
\hline Actinium-227 & & 16.2 & 99.77 & 0.23 & $1.2 \times 10^{-8}$ \\
\hline Lead-210 & & 58.5 & 93.12 & 6.88 & $1.8 \times 10^{-6}$ \\
\hline Polonium-210 & & 55.1 & 99.77 & 0.23 & $1.2 \times 10^{-8}$ \\
\hline Protactinium-231 & & 20.4 & 99.77 & 0.23 & $1.2 \times 10^{-8}$ \\
\hline Radium-226 & & 23.6 & 99.77 & 0.23 & $1.2 \times 10^{-8}$ \\
\hline Radium-228 & & 5.7 & 99.77 & 0.23 & $1.2 \times 10^{-8}$ \\
\hline Thorium-230 & & 458 & 99.77 & 0.23 & $1.2 \times 10^{-8}$ \\
\hline Thorium-232 & & 5.3 & 99.77 & 0.23 & $1.2 \times 10^{-8}$ \\
\hline Uranium-235 & & 1.28 & 99.77 & 0.23 & $1.2 \times 10^{-8}$ \\
\hline Uranium-238 & & 27.9 & 99.77 & 0.23 & $1.2 \times 10^{-8}$ \\
\hline
\end{tabular}

See next page for footnotes. 
TABLE 3 (Cont.)

a Based on an annualized daily average feed of 125 tons per day.

$b$ Estimated from the expected operating conditions for the vitrification and off-gas treatment systems.

c Chloride is released as hydrogen chloride $(\mathrm{HCl})$.

d Fluorides are not expected to volatilize and are therefore assumed to be released in the mineral form, e.g., apatite.

e Released as nitrogen dioxide $\left(\mathrm{NO}_{2}\right)$.

f Sulfate is released as sulfur dioxide $\left(\mathrm{SO}_{2}\right)$.

$g$ Fate of nitroaromatic compounds is based on an assumed destruction and removal efficiency of $99.9999 \%$. Partitioning between glass and scrubber sludge is based on an assumed treatment system efficiency of $99.9 \%$ and a destruction efficiency of $99.9 \%$.

$\mathrm{h}$ Thermal nitrogen oxides $\left(\mathrm{NO}_{\mathrm{x}}\right)$ are not present in the feed but are created from nitrogen and oxygen in the air; except for annual feed rates, quantities are reported as percentages of the $\mathrm{NO}_{\mathrm{x}}$-forming components of the feed (nitrates, nitrites, and organic nitro groups).

i The activities of actinium-227, protactinium-231, and uranium-235 are derived from the radiological source term analysis for the raffinate pit sludge (Table 2.3 of the baseline assessment [DOE 1992a]). Radon-222 is not included in this table because it was assumed that $100 \%$ of the radon is released to the atmosphere. It is estimated that about $100 \mathrm{Ci}$ of radon-222 would be released from the off-gas treatment system over a 4-year period.

Source: MK-Ferguson Company and Jacobs Engineering Group (1992b).

Two on-site disposal cell designs could be used for Alternative 7a (Figure 5). Because the vitrified waste would be chemically inert and the vitrified product very resistant to leaching, this material could be disposed of in a cell with a single foundation liner (the vitrification cell). The untreated waste (i.e., soil, sediment, and structural material with relatively low contaminant concentrations) could be stored in an adjacent cell (the combination cell) with a design similar to that identified for Alternative $6 \mathrm{a}$, except smaller. The total area covered by both cells would be about 17 ha ( 42 acres), 4.9 ha (12 acres) for the vitrification cell and 12 ha ( 30 acres) for the combination cell.

Good engineering practices and appropriate mitigative measures would be used during all excavation and construction activities to prevent or minimize potential erosion, dust emissions, and contaminant releases. Following completion of remedial action activities and closure of the treatment and storage facilities and disposal cell, the site would be renovated in the same manner as described for Alternative 6a. 


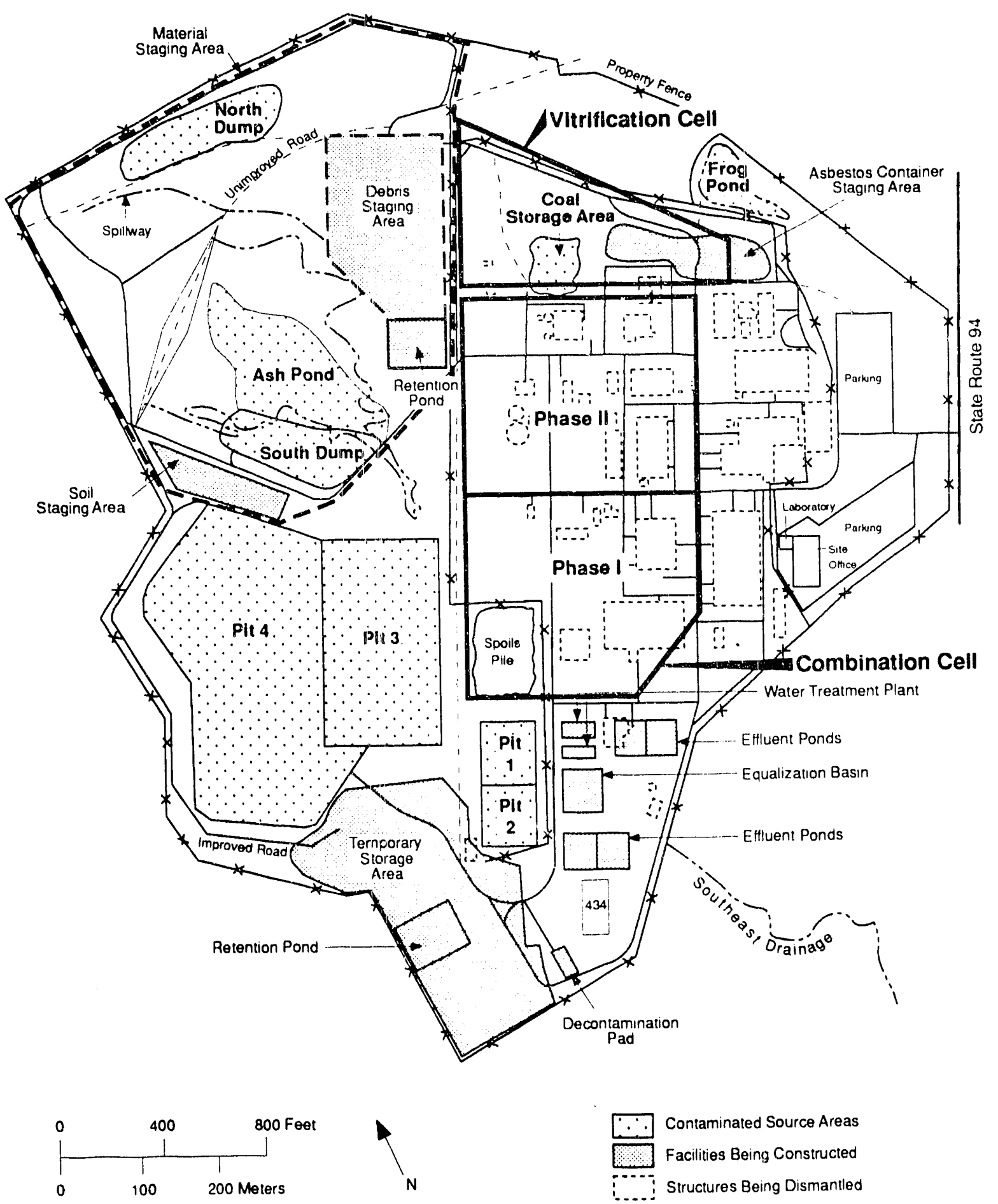

FIGURE 5 Conceptual Layout of the Vitrification Cell and Combination Cell for Alternative 7a (Source: DOE 1992b) 


\subsection{ALTERNATIVE 7b: REMOVAL, VITRIFICATION, AND DISPOSAL AT THE ENVIROCARE FACILITY}

Under Alternative $7 \mathrm{~b}$, contaminated material would be removed from source areas in the same manner as identified for Alternative 6a. The contaminated material would be treated in same manner as described for Alternative $7 a$ and would also require a volume reduction facility and a sludge processing facility with dewatering and vitrification processes. Material not vitrified would be delivered to a 4-ha (10-acre) staging and loading area located on-site. At this area, the untreated material would be placed into specially designed containers for off-site transport. These containers would be similar to those used for DOE's UMTRA program; the containers fit on railroad flatcars specially designed for their use.

Both the vitrification and volume reduction facilities would be equipped to directly load containers. After filling, the containers would be covered, sealed, and decontaminated. The filled containers would be placed onto low-bed trucks (one container per truck) equipped with brackets to secure the containers. The conta :rers would then be transported to a 4.5-ha (11-acre) rail siding near Wentzville, Missouri, where they would be transferred to the railroad flatcars for transport to the Envirocare facility near Clive, Utah. The Envirocare facility is currently accessible by a rail siding. At this siding, the containers would be transferred to trucks and then transported to a disposal cell with a design assumed to be similar to that identified for Alternative 7a (DOE 1992b).

Good engineering practices and appropriate mitigative measures would be used during all excavation and construction activities to prevent or minimize potential erosion, dust emissions, and contaminant releases. Following completion of remedial action activities and closure of the treatment facilities, the site would be renovated in : manner similar to that identified for Alternative 6a. Following removal of contaminated source areas, excavated areas would be backfilled with clean borrow and topsoil, and the site would be graded to incorporate broad, gently sloping drainage swales into natural drainage paths. The site would then be seeded with hardy, native vegetation.

\subsection{ALTERNATIVE 7c: REMOVAL, VITRIFICATION, AND DISPOSAL AT THE HANFORD FACILITY}

The removal and treatment of contaminated material under Alternative $7 \mathrm{c}$ is identical to that identified for Alternative $7 \mathrm{~b}$. Under Alternative $7 \mathrm{c}$, contaminated material from the Weldon Spring site would be placed in an engineered disposal cell located at the 200-West Area of the DOE Hanford facility near Richland, Washington. Packaging and transport of the treated and untreated material from the Weldon Spring site onto railcars at the Wentzville siding would be identical to that identified for Alternative $7 \mathrm{~b}$. The contaminated material would then be transported to the Hanford facility. The Hanford facility is currently accessible by a rail siding, and the waste containers would be transferred at the site to trucks and then transported to a disposal cell with a design similar to that identified for Alternative 7a. The disposal cell is assumed to require approximately 17 ha (42 acres), and cell design considerations and support facilities are assumed to be similar to those identified for Alternative 7a (DOE 1992b). 


\section{AFFECTED ENVIRONMENT}

\subsection{WELDON SPRING SITE}

The Weldon Spring site is located on the drainage divide of the Missouri and Mississippi rivers, about $2.4 \mathrm{~km}$ ( $1.5 \mathrm{mi})$ northwest of the Missouri River. The 88-ha (217-acre) chemical plant area contains about 40 buildings and structures, four man-made retention ponds (raffinate pits), two man-made ponds (Ash Pond and Frog Pond), and two former dump areas (Figure 6). These structures and areas are radioactively and/or chemically contaminated. Most of the area surrounding the chemical plant area is part of the MDOC Busch Wildlife Complex $(6,835$ ha $[16,890$ acres $])$. This complex consists of three wildlife areas: the August A. Busch Memorial Wildlife Area $(2,829$ ha $[6,987$ acres]) to the north of the chemical plant area, the Weldon Spring Wildlife Area (2,978 ha [7,356 acres]) to the south and east, and Howell Island Wildlife Area (1,031 ha [2,547 acres]) in the Missouri River to the southeast of the chemical plant (MDOC 1989).

Much of the chemical plant area (approximately 66 ha [162 acres]) is developed (i.e., industrialized) and contains grassland and old-field habitats that are subjected to periodic mowing. The remainder of the area (about 22 ha [55 acres] in the northwestern portion of the site) consists of relatively undisturbed old-field and upland forest habitat. In addition to a resident fauna, the chemical plant area (and particularly the northwestern portion of the site) is probably utilized by a number of species that move freely between on-site and off-site locations.

Aquatic habitats at the chemical plant area cover about 15 ha (38 acres) and include the raffinate pits, Ash Pond, Frog Pond, and the drainages from these poncis; all contain surface water, sediment, and soil that are radioactively and chemically contaminated. The on-site surface waters attract waterfowl and shorebirds, and large numbers of waterfowl have at times been observed using some of these habitats. Waterfowl that have been observed at the raffinate pits and Ash Pond include wood duck, mallard, blue-winged teal, scaup, and Canada goose (Hlohowskyj 1990).

The nearby wildlife areas (Figure 2) contain a variety of habitats, including grasslands, wetlands, forests, and cultivated fields of row crops and grasses; forest habitats are the most abundant and widespread. Existing aquatic habitats include over 30 lakes and 60 ponds. A total of 29 mammal species, 47 reptile species, 25 amphibian species, and 105 fish species have been reported from St. Charles County (Dickneite 1988), and many of these species occur at the wildlife areas. At least 277 avian species having been reported from the wildlife areas (MDOC 1991), and more than 100 species breed in the area.

\subsection{WENTZVILLE RAIL SIDING}

The proposed rail siding that could be constructed under Alternatives $7 b$ and $7 c$ would be located along the existing rail lines in the town of Wentzville, Missouri. Wentzville is 


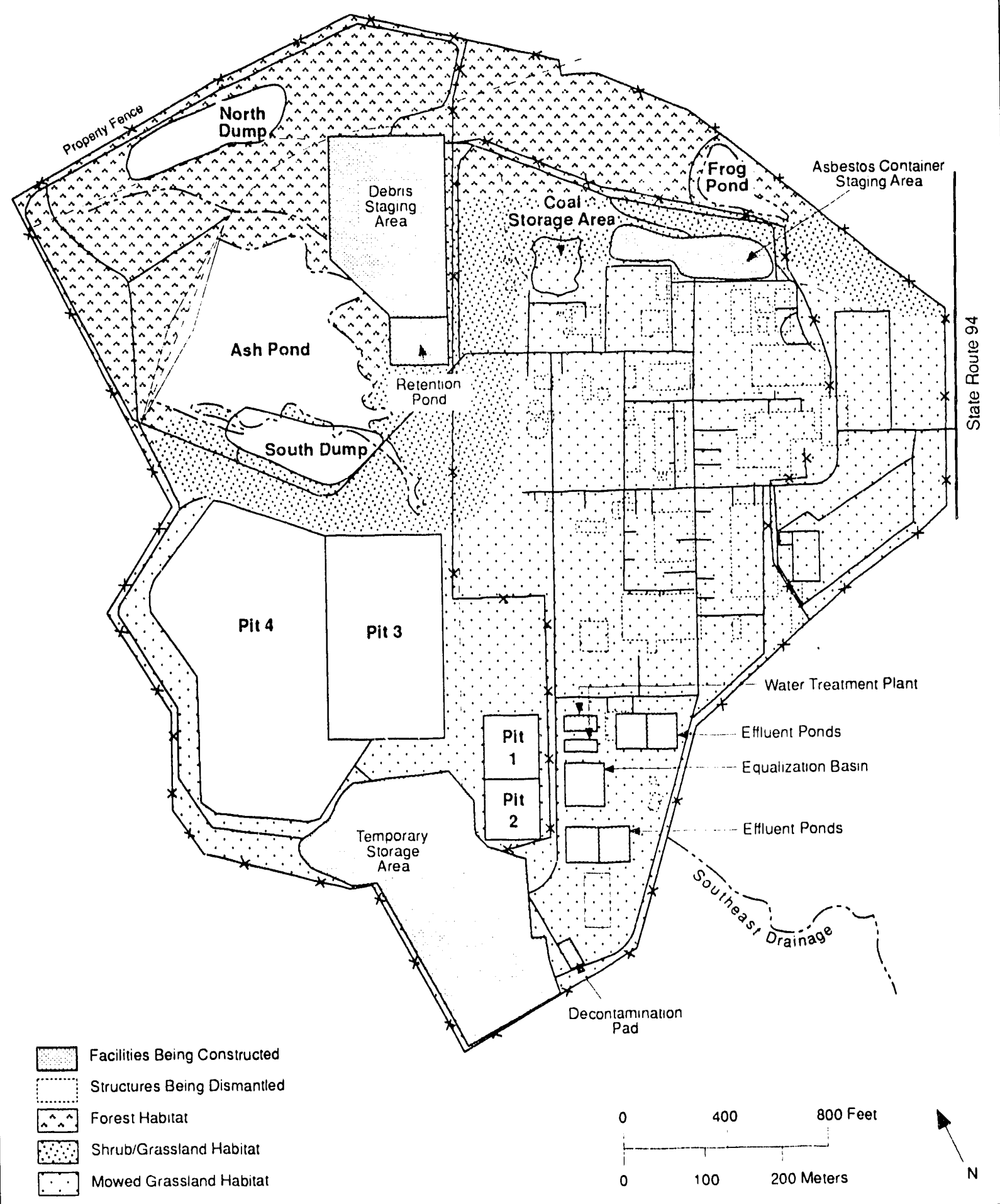

FIGURE 6 Terrestrial and Aquatic Habitats at the Weldon Spring Site (Source: DOE 1992a, Figure 7.2) 
approximately $24 \mathrm{~km}(15 \mathrm{mi})$ northwest of the Weldon Spring site. No wetlands (U.S. Fish and Wildlife Service 1989) or floodplains (Federal Insurance Administration 1978) are located along the existing rail lines, and no state-listed species or sensitive communities are known to occur in the Wentzville area (Dickneite 1991). The area currenily contains several rail sidings and is served by both the Union Pacific and Burlington Northern railroads (DOE 1992b).

\subsection{ENVIROCARE SITE}

The Envirocare site near Clive, Utah, contains a commercial disposal facility licensed by the state of Utah for naturally occurring radioactive material (NORM), as well as mixed NORM and chemically hazardous waste. The site is located on the eastern edge of the Great Salt Lake Desert in Tooele County, Utah, approximately $129 \mathrm{~km}(81 \mathrm{mi})$ west of Salt Lake City (Figure 7). The Envirocare site occupies approximately 220 ha (540 acres) in a county set-aside area zoned for radioactive waste disposal, and is located approximately $0.62 \mathrm{~km}(1 \mathrm{mi})$ south of a rail switch point identified as Clive (Figure 8). Approximately 40 ha (100 acres) adjacent to the site is the disposal location for uranium mill tailings removed from Salt Lake City as part of the UMTRA program (Envirocare of Utah 1991). Much of the land surrounding the Envirocare site is public domain administered by the U.S. Bureau of Land Management (DOE 1984).

The. Envirocare site is situated in an arid desert area rated by the Bureau of Land Management as being poor for grazing or forage production. Vegetation at the site is a homogeneous, semidesert low shrubland, composed primarily of shadscale (Figure 9). This shrubland is part of the northern desert shrub biome of the cold desert formation and has been described as a saltbrush (shadscale)-greasewood shrub complex (DOE 1984). Plant communities identified in the area are shadscale-gray molly, black greasewood-Gardner saltbrush, and a shadscale-gray molly/black greasewood transitional community (Figure 8); all three communities are low in species diversity. The vegetation forms an important ground cover that provides habitat for wildlife.

Animal species reported from the area - all of which may breed or nest there include black-tailed jackrabbit, deer mouse, grasshopper mouse, horned lark, and desert horned lizard (Envirocare of Utah 1991). No wetlands or other aquatic habitats are present at or in the vicinity of the Envirocare facility. The nearest stream channel ends approximately $3 \mathrm{~km}(1.9 \mathrm{mi})$ east of the site, and the nearest body of permanent surface water is Big Spring, about $45 \mathrm{~km}$ $(28 \mathrm{mi})$ east of the facility.

\subsection{HANFORD SITE}

The Hanford site (comprising approximately $1,450 \mathrm{~km}^{2}$ [560 $\left.\mathrm{mi}^{2}\right]$ ) is located within the Pasco Basin of the Columbia River, a semiarid region of desert in southeastern Washington State. Because the site includes widely spaced clusters of industrial buildings, much of this desert is undeveloped. The developed areas account for only about $6 \%$ of the total land area of the site. No livestock grazing or tillage has occurred there since the early 1940 s. 


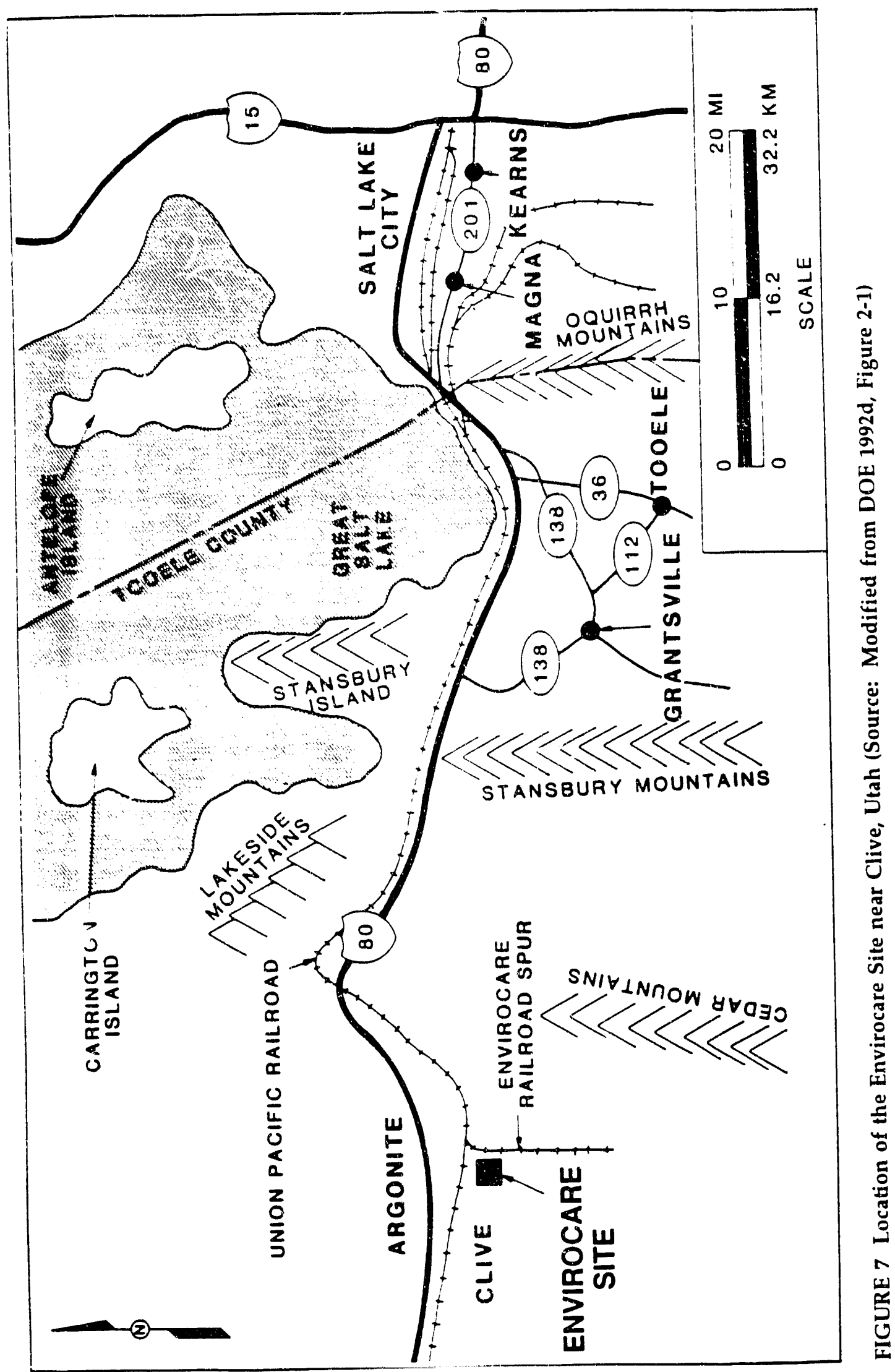




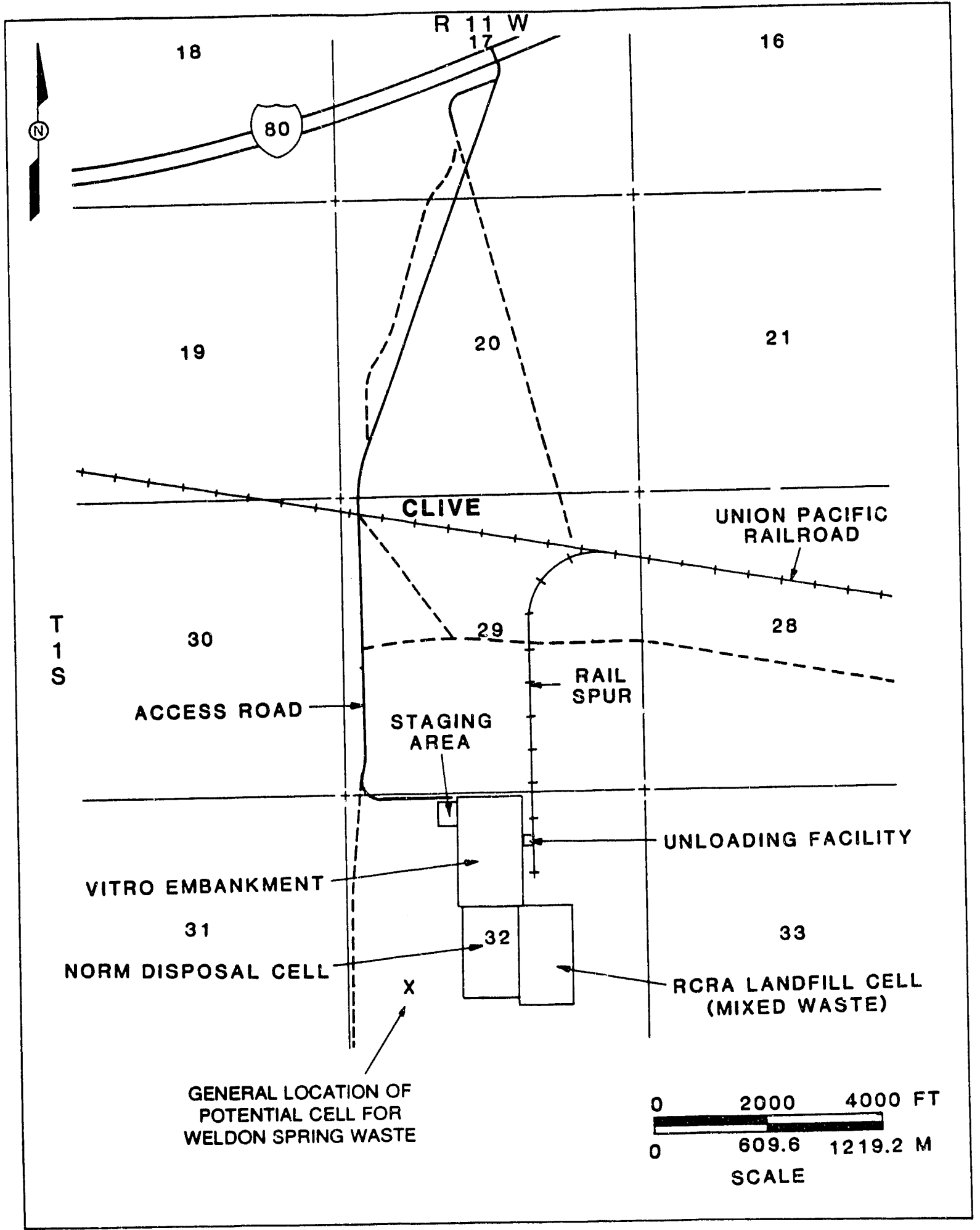

FIGURE 8 Operational Areas within the Envirocare Site (Source: Modified from DOE 1992d, Figure 2-2) 


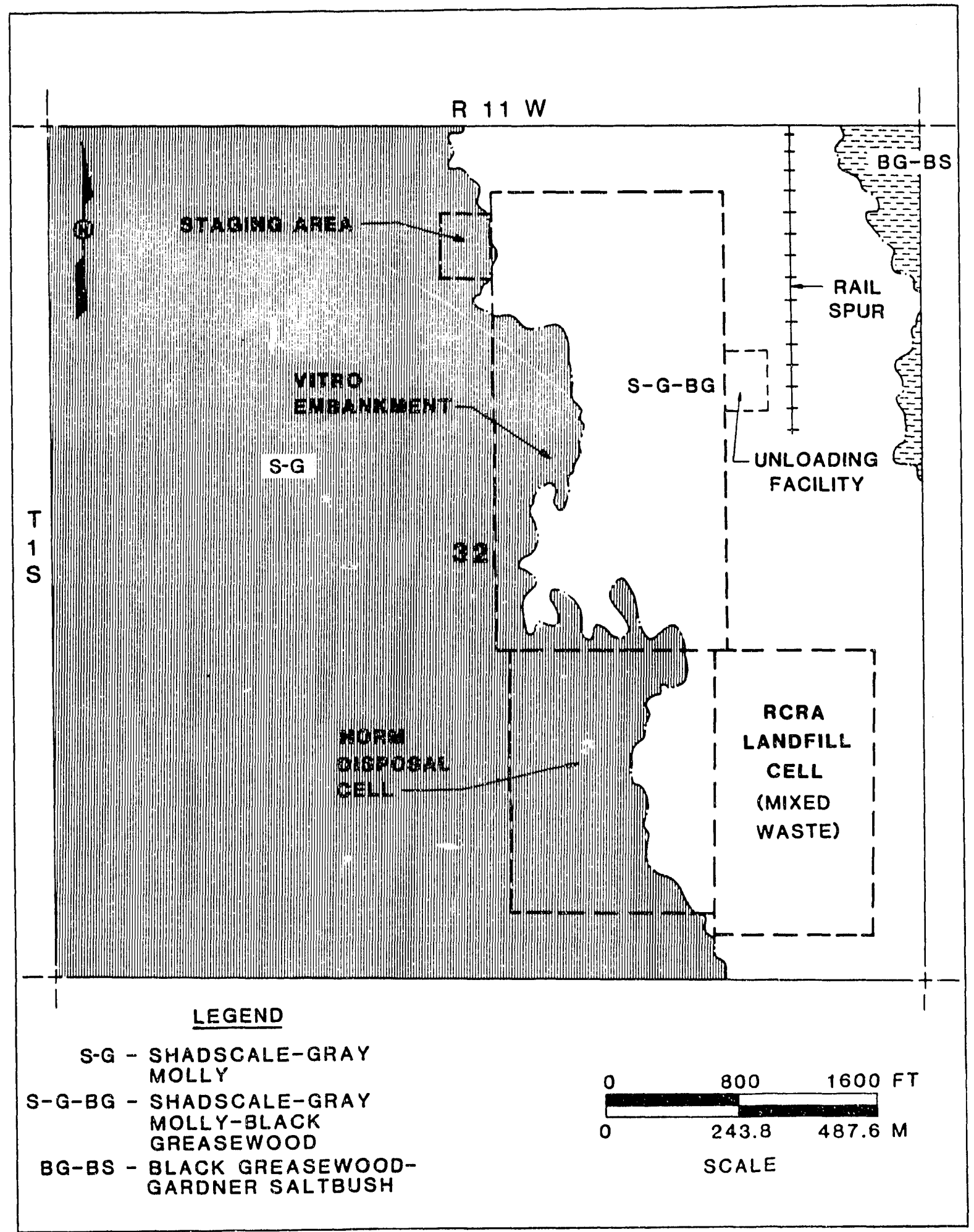

FIGURE 9 Vegetation Map of the Envirocare Site (Source: Modified from DOE 1992d, Figure 2-4) 
The Columbia River flows through the northern part of the site and forms the site's eastern boundary (Figure 10). This section of the Columbia River, referred to as the Hanford Reach, is the largest free-flowing portion of the river; however, the daily and seasonal water fluctuations have been altered by dams upstream and downstream of the site (Pacific Northwest Laboratory 1991). The major portion of the site provides a buffer around the smaller areas used for production of nuclear materials, research, and waste management and disposal. This bulfer is composed of several national and state wildlife refuges, including the Saddle Mountain National Wildlife Refuge and the state Wahluke Wildlife Refuge Area to the north, the Arid Lands Ecology Reserve to the west and southwest, the state Rattlesnake Slope Wildlife Refuge Area to the southwest, and the McNary National Wildlife Refuge to the east along the Columbia River (Figure 11). The location evaluated for the potential off-site disposal cell is the 200-West Area of the 200-Area plateau. This area contains the Hanford waste management facilities and the Plutonium Processing Facility (DOE 1991).

The Hanford site is characterized by shrub-steppe desert that supports numerous plant and animal species adapted to a semiarid environment (Pacific Northwest Laboratory 1991). The site supports eight major vegetation types (Figure 12). The potential disposal cell would be located in the 200-West Area, which is dominated by the sagebrush/cheatgrass or sagebrush/ Sandberg's bluegrass community type. More than 100 plant species occur in the 200-Area plateau, and mosses and lichens are common on the soil surtace. Because of past grazing, cheatgrass accounts for $50 \%$ of the plant cover in the 200-Area plateau (Pacific Northwest Laboratory 1991).

The Hanford site contains no marshes, estuaries, or designated wetlands. The banks of the Columbia River (and its islands) afford some semiaquatic habitat. Of the three ponds on-site, only one (West Lake, near the 200-East Area) is natural. The remainder are semipermanent artificial ponds created for the disposal of cooling water. These ponds are dominated by cattails, reeds, and trees such as willow, cottonwood, and Russian olive.

Several passerine bird species - including the sage sparrow, sage thrasher, and loggerhead shrike - rely on sagebrush or bitterbrush for nesting habitat, the vegetation type typical of the 200-West Area. Bitterbrush is also an important browse for mule deer. Mature sagebrush and bitterbrush burn readily, creating habitat devoid of shrubs that is suitable for ground-nesting birds such as the long-billed curlew, horned lark, Western meadowlark, and burrowing owls. More than 125 species of birds are found throughout the site.

Approximately 30 species of mammals and more than 300 species of terrestrial and aquatic insects have been documented on the Hanford site (Pacific Northwest Laboratory 1991). Abundant mammal species include the Great Basin pocket mouse, deer mouse, Townsend's ground squirrel, Northern pocket gopher, Western harvest mouse, sagebrush vole, and Merriam's shrew. The principal predator is the coyote. Grasshoppers and darkling beetles are the most conspicuous groups of insects and form important components of the prey base of birds and mammals. Sixteen species of amphibians and reptiles have been observed at the site. The side-blotched lizard is the most common and is found throughout the site. 


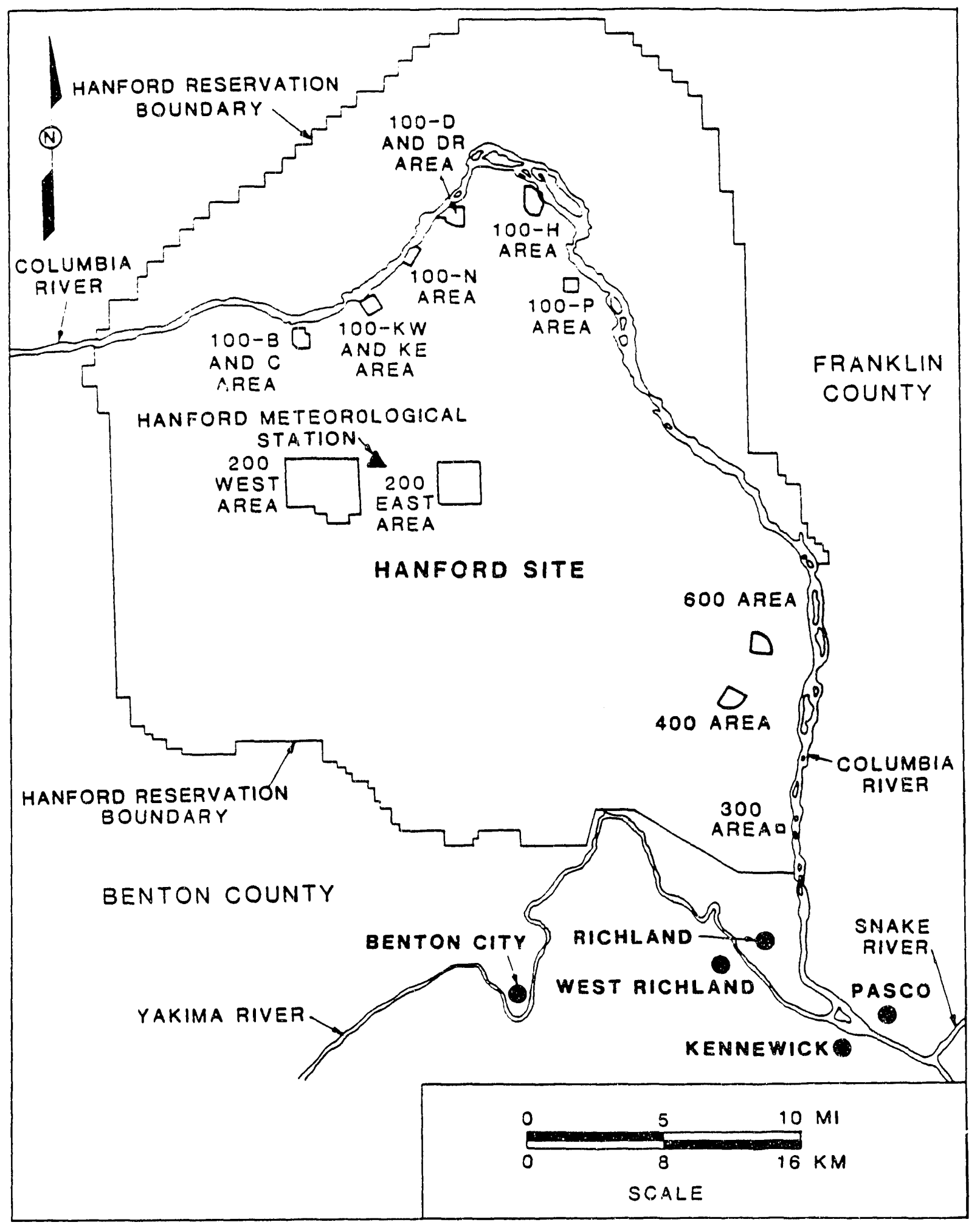

FIGURE 10 DOE Operational Areas within the Hanford Site (Source: Modified from DOE 1992d, Figure 3-2) 


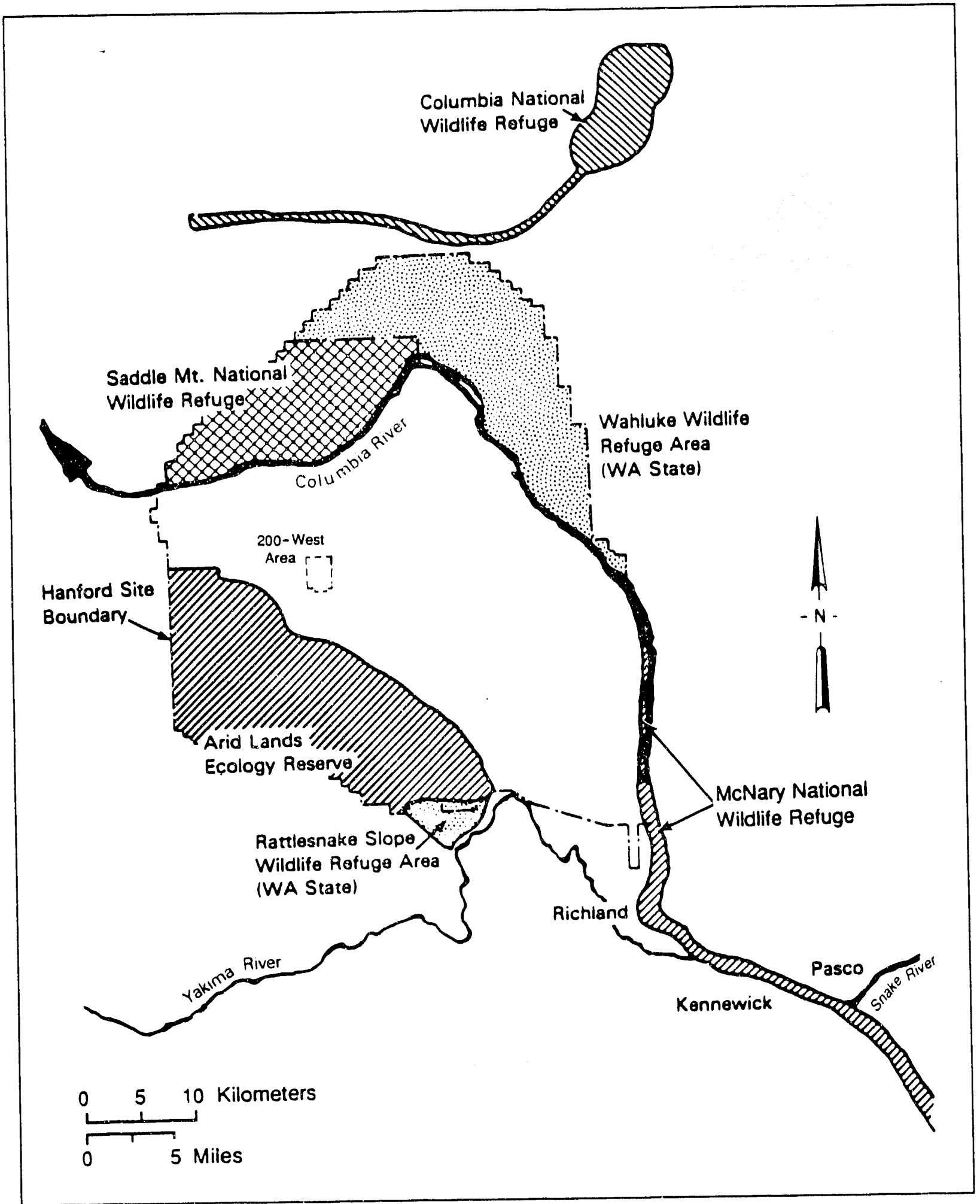

FIGURE 11 National and State Wildlife Refuges in the Vicinity of the Hanford Site (Source: Modified from Pacific Northwest Laboratory 1991, Figure 5.7) 


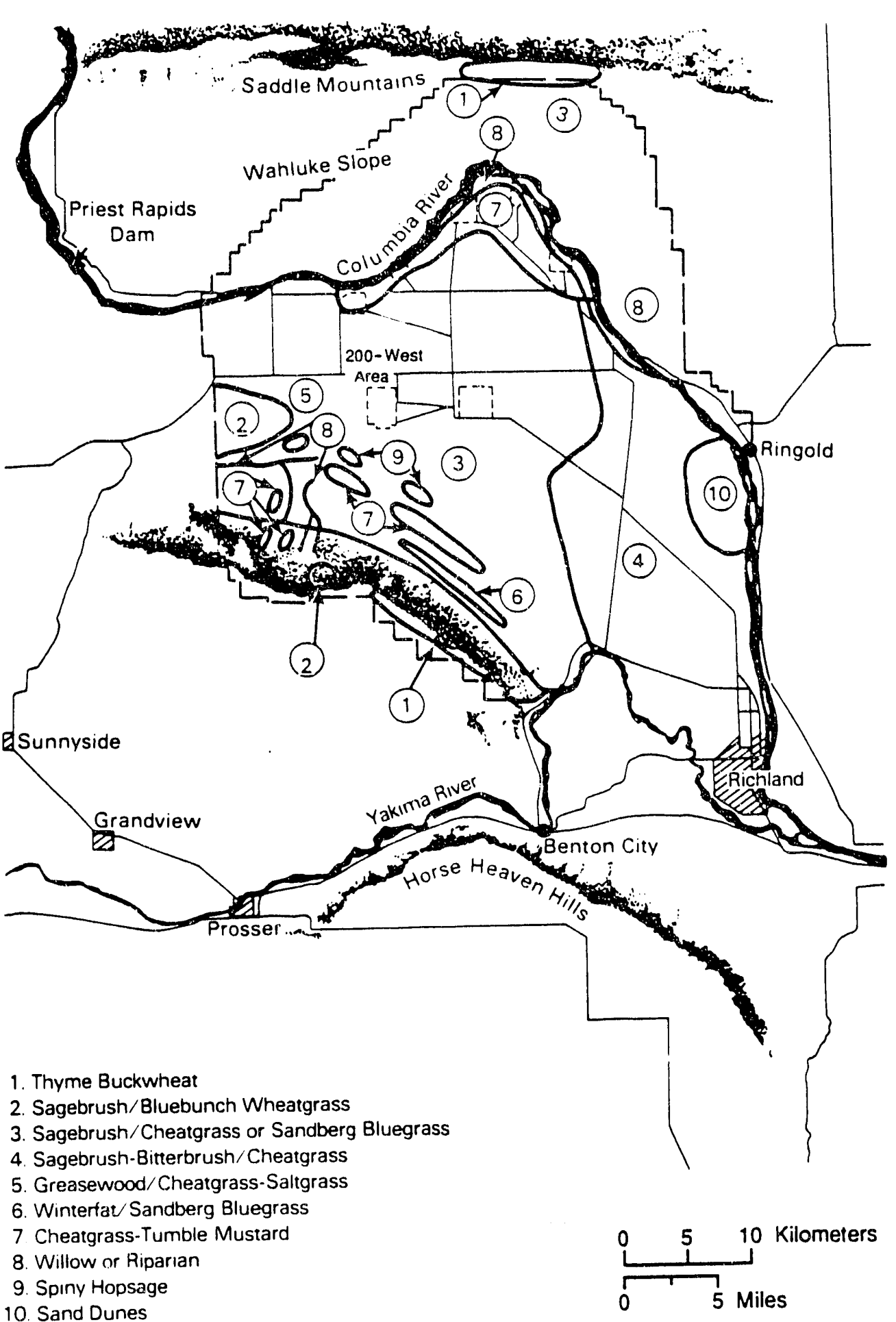

FIGURE 12 Distribution of Vegetation Types on the Hanford Site (Source: Modified from Pacific Northwest Laboratory 1991, Figure 5.2) 


\section{THREATENED AND ENDANGERED SPECIES}

Species listed as threatened or endangered and candidate species and species under status review (see Section 5) potentially occurring in areas that could be affected by the remedial action alternatives were identified through informal consultations with the U.S. Fish and Wildlife Service (Tieger 1988; Brabander 1990, 1991, 1992; Gloman 1991; Johnson 1991; Benton 1992; Charbonneau 1992; Flotlin 1992), the MDOC (Dickneite 1988, 1991; Gaines 1988; Dieffenbach 1990; Figg 1991); and the Utain Department of Natural Resources (Fairchild 1991). Letters of consultation with the U.S. Fish and Wildlife Service are reproduced in Appendix J of the FS (DOE 1992b).

The term critical habitat for a threatened or endangered species means the specific areas within the geographical area occupied by the species on which are found those physical or biological features essential to the conservation of the species and which may require special management considerations or protection. Designated critical habitat may also include specific areas outside the geographical area occupred by the species that have been determined by the Secretary of the Interior (or Commerce) to be essential for conservation of the species.

\subsection{WELDON SPRING SITE}

\subsubsection{Bald Eagle (Haliaeetus leucocephalus) - Endangered}

The bald eagle is listed as endangered in Missouri. This bird of prey inhabits much of North America from the Arctic to the Gulf of Mexico. Generally, this species nests within $0.8 \mathrm{~km}$ $(0.5 \mathrm{mi})$ of water and feeds on fish and waterfowl. Populations of this once common species declined since the mid 1800 s because of factors such as pesticides in prey, habitat loss and fragmentation, and hunting. Since the species was listed (1967), populations in some areas (e.g., Wisconsin and Michigail) have been increasing. The bald eagle is known to occur at the Busch Wildlife Area where it is an uncommon spring and fall visitor (MDOC 1991). Bald eagles use the Howell Island Wildlife Area as a roost site in winter (Gaines 1988; Brabander 1992). The bald eagle has been sighted in St. Charles County on the last six bald eagle winter counts, and an average of 25 have been sighted in the county each year. No suitable or designated critical habitat for this species has been identified at the chemical plant area or at areas proposed for remediation under the current action.

\subsubsection{Peregrine Falcon (Falco peregrinus) - Endangered}

Peregrine falcons are typically found near wetlands (rivers, marshes, estuaries, and shorelines) and in open country. They feed principally on songbirds, shorebirds, and waterfowl, capturing their prey on the wing. Foraging occurs over large areas. The peregrine falcon nests on cliff faces, river banks, in abandoned raptor nests, and on buildings. Like bald eagles, peregrine populations have been seriously affected in the past by pesticide use, particularly DDT. 
(dichlorodiphenyltrichloroethane). Captive breeding programs and a ban on DDT use have contributed to the reestablishment of peregrine populations nationwide. Transient occurrences of peregrine falcons have been reported from St. Charles County (Gaines 1988), and the species is considered a casual spring and fall visitor at the Busch Wildlife Area but is not observed every year (MDOC 1991). The nearest hack site is located about $48 \mathrm{~km}$ (30 mi) east of the chemical plant in downtown St. Louis (Charbonneau 1992). No designated critical habitat for this species has been identified in the vicinity of the chemical plant area.

\subsubsection{Interior Least Tern (Sterna antillanim) - Endangered}

Least terns nest on bare to sparsely vegetated beaches, including salt flats, sand and gravel tars, spits, and islands (U.S. Fish and Wilcllife Service 1988). Small nesting colonies occur on large open sandbars along the Mississippi River in Missouri (MDCS 1984). At one time, nesting also occurred along the Missouri River (MDOC 1984). Populations of this species have been declining as a result of habitat loss and degradation following dam construction, stream channelization, and water withdrawals for irrigation (MDOC 1984; U.S. Fish and Wildlife Service 1988). Transient occurrences of this bird have been reported during the summer from St. Charles County (Gaines 1988). It is known to visit the Busch Wildlife Area where it is considered a casual spring and fall visitor that may not be observed every year (MDOC 1991). The least tern forages on small fish and insects. No nesting habitat is known in the Missouri River in the vicinity of the Weldon Spring site (Charbonneau 1992), and no designated critical habitat exists at the chemical plant area, although migratory individuals may forage at the on-site wetlands and the off-site lakes.

\subsubsection{Pallid Sturgeon (Scaphirhynchus albus) - Endangered}

The pallid sturgeon is a large bottom-dwelling fish found primarily in large turbid rivers, where it lives in strong currents over areas with sandy or gravelly bottoms. In Missouri, this species is restricted to the Missouri River and to a small section of the Mississippi River from its confluence with the Missouri River to a few miles upstream (Pflieger 1975). Although little is known about the life history of this species, spawning is between early June and early August (Pflieger 1975). It feeds on aquatic insects and small fish. The pallid sturgeon has been reported from the Missouri River near the Weldon Spring site (Gaines 1988; Brabander 1992). This species has been reported from the Missouri River at the U.S. Route 40/61 crossing of the Daniel Boone Bridge (Gaines 1988), approximately $5 \mathrm{~km}$ (3 mi) downstream of the confluence of the Southeast Drainage with the Missouri River (Gaines 1988; MDOC 1989).

\subsubsection{Decurrent False Aster (Boltonia decurrens) - Threatened}

The decurrent false aster (known as "starwort" in Missouri) is a composite that can be found on alluvial soils bordering sloughs, ditches, ponds, and streams. It has been reported from St. Charles County at two locations along the Missouri River (Figg 1991). The decurrent 
false aster has not been documented from the Weldon Spring area and is not expected to occur at the chemical plant area (Brabander 1992).

\subsection{WENTZVILLE RAIL SIDING}

No listed species are expected to occur at the Wentzville rail siding (Brabander 1991).

\subsection{ENVIROCARE SITE}

\subsubsection{Bald Eagle (Haliaeetus leucocephalus) - Endangered}

The bald eagle is listed as endangered in Utah, where it is primarily a winter resident. Two active nests have been documented in the southeastern portion of Utah, and the state supports one of the largest wintering populations of bald eagles in the country (Johnson 1991). Birds usually begin arriving in mid November and leave by March. Rush Valley - located about $48 \mathrm{~km}$ ( $30 \mathrm{mi}$ ) east of the Envirocare site - supports one of the largest concentrations of bald eagles in Utah; as many as 200 birds have been counted in this area. Skull Valley, about $24 \mathrm{~km}(15 \mathrm{mi})$ east of the Envirocare site, supports a smaller number of wintering bald eagles. No eagles are known to overwinter in the immediate vicinity of the Envirocare site and no designated critical habitat is present at the site; this species possibly occurs in the general vicinity of the potential disposal cell.

\subsubsection{Peregrine Falcon (Falco peregrinus) - Endangered}

The endangered peregrine falcon is uncommon in Utah. The Utah Division of Wildlife Resources and the Peregrine Fund (Boise, Idaho) have been attempting to reintroduce this species to the state (Johnson 1991). Hack towers have been erected around the Great Salt Lake in an effort to establish a core population in the surrounding marshes (Johnson 1991). One hack site constructed on the north end of the Stansbury Mountains near Timpie, Utah, now supports a nesting pair of peregrine falcons that are returning to use the box. This site is approximately $42 \mathrm{~km}(26 \mathrm{mi}$ ) east of the Envirocare site. A second hack site, on Antelope Island about $89 \mathrm{~km}$ $(55 \mathrm{mi})$ northeast of the site, is also being used by a pair of falcons. No nesting habitat for this species occurs at the Envirocare site.

\subsection{HANFORD SITE}

\subsubsection{Bald Eagle (Haliaeetus leucocephalus) - Threatened}

The bald eagle is listed as threatened in Washington. It is a winter resident along the Columbia River, feeding on dead salmon and waterfowl, but it does not nest on the Hanford site. From 1980 to 1990 , the number of wintering eagles ranged from 35 to 55 ; one-third to one-. 
half of these were adults. A bald eagle roost has been documented on the Columbia River at a point $16 \mathrm{~km}(10 \mathrm{mi})$ north of the 200 Area (Flotlin 1992). Although no inland surveys have been conducted for bald eagles, they are not expected to occur near the 200-West Area because of the absence of suitable foraging or roosting habitat in the area and because of the distance (about $8 \mathrm{~km}[5 \mathrm{mi}]$ ) from the Columbia River.

\subsubsection{Peregrine Falcon (Falco peregrinus) - Endangered}

The peregrine falcon is an occasional spring and autumn migrant through the Hanford area, but it does not nest there. Old records indicate that there were 12 historic nest sites in the Hanford area (DOE 1991). Currently, seven nesting pairs are present in the state of Washington. In winter, total numbers increase as migrants pass through the area. No inland surveys have been conducted for peregrine ialcons; however, their prey is usually associated with the Columbia River (DOE 1991). As a result, the 200-West Area is not likely to be used by peregrine falcons, although some birds might venture inland from the Columbia River in search of songbirds. 


\section{CANDIDATE SPECIES OR SPECIES UNDER STATUS REVIEW}

The species described in Sections 5.1 and 5.4 have been classified as Category 2 (C2) species by the U.S. Fish and Wildlife Service (1991b). A taxon is listed as C2 when the Fish and Wildlife Service has information that indicates that proposing to list the species as endangered or threatened is possibly appropriate but conclusive data on biological vulnerability and threat are not currently available. Taxa classified as C2 are considered to be candidates for possible addition to the List of Endangered and Threatened Wildlife (U.S. Fish and Wildlife Service 1991a). The status of the long-billed curlew (see Section 5.4.1) has recently been changed from C2 to 3C; a $3 C$ status indicates that the taxon has proven to be more abundant or widespread than previously believed and/or is not subject to any identifiable threat.

\subsection{WELDON SPRING SITE}

\subsubsection{Sicklefin Chub (Macrohybopsis meeki) - C2 Status}

The sicklefin chub occurs throughout the Missouri River and in the Mississippi River downstream from the Missouri (Pflieger 1975). This small fish $(<10 \mathrm{~cm} \mathrm{[4} \mathrm{in.])} \mathrm{is} \mathrm{restricted} \mathrm{to}$ the main channels of large turbid rivers with a bottom of sand or fine gravel. Although this species is presumed to be a bottom feeder, little is known about its food habits (Pflieger 1975). Because of its numerous taste buds, the sicklefin chub is thought to be a specialist feeder, locating food by taste. Young have been collected from the Missouri River in July, suggesting that spawning is likely to be in spring (Pflieger 1975). This species occurs in the Missouri River in the vicinity of the Weldon Spring site (Brabander 1992). The sicklefin chub has been reported from the Missouri River at the U.S. Route 40/61 Daniel Boone Bridge, about $5 \mathrm{~km}$ (3 mi) downstream of the confluence of the Southeast Drainage with the Missouri River (Gaines 1988; MDOC 1989); near Pelican Island in St. Charles County, about $45 \mathrm{~km}$ (28 mi) downstream from the mouth of the Southeast Drainage (Figg 1991); and $1.6 \mathrm{~km}(1.0 \mathrm{mi})$ north of Creve Coeur Airport in the Missour: River in St. Charles County (Figg 1991).

\subsubsection{Sturgeon Chub (Macrohybopsis gelida) - C2 Status}

The distribution and habitat requirements of the sturgeon chub are very similar to the sicklefin chub. This small fish $(<8 \mathrm{~cm}[3 \mathrm{in.}])$ does not enter tributary streams, and it is not found in the Mississippi River north of its confluence with the Missouri River. Neither the feeding behavior nor the reproductive habits of this species are known (Pflieger 1975). Like the sicklefin chub, the sturgeon chub occurs in the Missouri River in the vicinity of the Weldon Spring site (Gaines 1988; Figg 1991; Brabander 1992). It has been reported from the Missouri River near the U.S. Route 40/61 Daniel Boone Bridge (Gaines 1988) and near Pelican Island in St. Charles County (Figg 1991). 


\subsubsection{Alligator Snapping Turtle (Macroclemys temminckii) - C2 Status}

The very large alligator snapping turtle is an aquatic turtle that ranges from northern Florida to southeastern Kansas, Missouri, and Illinois. The preferred habitats of this species include deep sloughs, oxbow lakes, and deep inuddy pools of large rivers (Johnson 1987). This turtle spends most of its time in the muddy bottom of deep water, in root snags, and in other hiding places. At night it tends to actively forage, whereas it spends the day in hiding and in passive fishing by means of a lure-like tongue (Carr 1952). The alligator snapping turtle feeds primarily on fish, but has been known to eat small turtles. Reproductive maturity is achieved at about 11 to 13 years. Courtship and breeding occur in late spring and take place in water. The eggs, which are buried in banks above the water line, hatch in late summer (Johnson 1987). Water pollution, habitat degradation, and overharvesting have contributed to the reduced numbers of this species. The alligator snapping turtle has not been collected or observed in the Weldon Spring Wildlife area and is not expected to occur in the area because of the absence of suitable habitat (Miller 1991).

\subsubsection{Eastern Massasauga (Sistrurus catenatus catenatus) - C2 Status}

The eastern massasauga is one of two subspecies of the massasauga rattlesnake (Johnson 1987). In Missouri, the eastern massasauga is found in marshes or moist prairies that are within or near large river floodplains. This species is active from April through October, with much time spent basking during warm sunny days, and it feeds primarily on voles, deer mice, and small snakes. Courtship and breeding take place in spring or autumn, but litters may be produced only every other year (Johnson 1987). The distribution of this species in Missouri has become restricted to a few isolated areas in the eastern, north-central, and northwestern portions of the state as a result of habitat loss. The eastern massasauga is known from St. Charles County (Johnson 1987; Figg 1991; Brabander 1992); the nearest sighting was approximately $10 \mathrm{~km}(6 \mathrm{mi})$ north of the Weldon Spring site (Charbonneau 1992).

\subsubsection{Bachman's Sparrow (Aimophila aestivalis) - C2 Status}

The Bachman's sparrow ranges over the southeastern United States north to Pennsylvania and Ohio (Terres 1980). In Missouri, this species is near the northern edge of its range, where typical nesting habitat is abandoned fields dominated by goldenrods, asters, and grasses. This sparrow nests from April to July, in nests usually built on the ground and constructed primarily of fine grasses (Bent 1968). Because this bird is so secretive, little is known about its life history, particularly its courtship behavior. Bachman's sparrow forages on the ground, feeding on insects and seeds (Terres 1980). Habitat destruction and dependence on ephemeral, early-successional vegetation appear to be likely causes for its decline (MDOC 1984). This species is listed as a casual spring and summer resident at the Busch Wildlife Area, but there have been no records of breeders for at least 18 years (MDOC 1991). 


\subsubsection{Loggerhead Shrike (Lanius ludovicianus) - C2 Status}

The loggerhead shrike is a southern Nearctic species, with a breeding range extending from southern Canada to the highlands of southern Mexico (Peterson 1980). This species inhabits semiopen country, thinly wooded or scrubby lands with clearings, meadows, pastures, old orchards with thickets, and hedges (Terres 1980). During winter, the loggerhead shrike feeds largely on mice and small birds; in summer, insects become a large component of the diet (Terres 1980). This species is identified as occurring in the Busch Wildlife Area in all seasons, sparingly recorded but generally every year (MDOC 1991), and is a probable nesting species in the area. Four loggerhead shrikes have been observed near the Weldon Spring site at the proposed borrow area (Thomas 1992).

\subsection{WENTZVILLE RAIL SIDING}

No candidate $(\mathrm{C} 2)$ species or designated critical habitats have been identified at the site of the Wentzville rail siding (Brabander 1991).

\subsection{ENVIROCARE SITE}

No candidate (C2) species have been identified as occurring at the Envirocare site (Johnson 1991).

\subsection{HANFORD SITE}

\subsubsection{Long-Billed Curlew (Numenius americanus) - 3C Status}

The status of the long-billed curlew has been changed from C2 (Gloman 1991) to 3C (Flotlin 1992), so the species is not discussed in this document.

\subsubsection{Ferruginous Hawk (Buteo regalis) - C2 Status}

The ferruginous hawk nests on cliffs, in trees, and on transmission towers. It is known to nest on transmission towers at the Hanford site (DOE 1991); however, these nests are more than $16 \mathrm{~km}(10 \mathrm{mi})$ from the 200-West Area (Weiss 1992). This hawk feeds on a variety of animals, including snakes and pocket gophers. A once common species, it has been declining because of conversion of native shrub-steppe habitat to agriculture, water diversion and impoundment, and urbanization. In 1987, 63 nesting pairs were reported from Washington (DOE 1991). The ferruginous hawk may forage in the 200-West Area. 


\subsubsection{Western Sage Grouse (Centrocercus urophasianus phaios) - C2 Status}

The western sage grouse almost exclusively inhabits areas dominated by sagebrush (Artemisu tridentata). It prefers level to gently rolling sites with slopes of less than $30 \%$ (DOE 1991). Breeding occurs during late spring in open areas of bare (or nearly bare) ground, called leks, ranging in size from 4 to 40 ha (10 to 100 acres). These leks are usually adjacent to nesting and brood-rearing habitat, characterized by 20 to $40 \%$ cover of late-successional sagebrush. During winter, the sage grouse moves to lower elevations, free of snow, and feeds almost solely on sagebrush leaves. Throughout the vear, sagebrush accounts for over $60 \%$ of its diet. Population decline has been attributed to habitat loss resulting from military training exercises, land conversion to agriculture, habitat degradation resulting from livestock grazing, and wildfire (DOE 1991). The western sage grouse population at the Hanford facility is small and appears to be confined to the slopes of the Rattlesnake Hills, about $8 \mathrm{~km}(5 \mathrm{mi})$ south of the 200-West Area (Pacific Northwest Laboratory 1991). Only one or two birds are sighted annually near Rattlesnake Hills, and no broods have been seen since 1976 (DOE 1991); however, no systematic surveys have been conducted.

\subsubsection{Black Tern (Chlidonias niger) - C2 Status}

The black tern nests in prairie sloughs and marshes from Canada, south to Ohio and as far east as New England, and winters along, seacoasts. It nests in late spring and summer in small, loose colonies on mats of dead vegetation. The black tern forages over marshes and meadows feeding on insects. This species also forages in shallow water, feeding on small fish, crustaceans, and mollusks (Terres 1980). No black terns have been reported from the Hanford site, and the only suitable habitat in the area is likely to be along portions of the Columbia and Yakima rivers. Because of the absence of surface waters and marshes, none are expected in the 200-'Nest Area.

\subsubsection{Loggerhead Shrike (Lanius ludovicianus) - C2 Status}

The loggerhead shrike is a southern Nearctic species, with a breeding range extending from southern Canada to the highlands of southern Mexico (Peterson 1980). This species inhabits semiopen country, thinly wooded or scrubby land with clearings, meadows, pastures, old orchards with thickets, and hedges (Terres 10\%3). During winter, the loggerhead shrike feeds large!y on mice and small birds; in summer, insects become a large component of its diet (Terres 1980). This species has been reported from sagebrush areas at the Hanford site and may utilize the 200-West Area ior nesting and foraging (Pacific Northwest Laboratory 1991).

\subsubsection{Bull Trout (Salvelinus confluentus) - C2 Status}

Before construction of dams and the introduction of warmwater fishes, the bull trout was one of the dominant predatory fish in the Columbia basin (Li et al. 1987). The range of th: large species (>9 kg [20 lb]) includes coastal and mountain streams of the Arctic, Pacific, and 
Missouri river drainages; it is present from the southern Yukon to the headwaters of the Columbia River drainage, northern Nevada, and the McCloud River drainage in northern California (Page and Burr 1991). The habitat of the bull trout is deep pools in large cold rivers and lakes, and the species is rarely anadromous. This, and other species, have been impacted by dam-related habitat changes and the introduction of exotic warmwater fish assemblages, although few exotics have yet become established in the Hanford Reach of the Columbia River (Li et al. 1987). The bull trout has been collected from the Hanford Reach of the Columbia River (Neitzel 1992), but no suitable habitat for this species occurs in the 200-West Area.

\subsubsection{California Floater (Anodonta califomiensis) - C2 Status}

The California floater, a mollusk, occurs in flowing stretches of rivers in the Pacific Northwest, especially in those with a rocky bottom. It has been reported from the Snake River in Washington and ldaho but not from the Hanford Reach of the Columbia River or from the Yakima River (Neitzel 1992). No suitable habitat for this species occurs in the 200-West Area.

\subsubsection{Columbia Pebblesnail (Fluminicola columbianus) - C2 Status}

Like most gastropod mollusks, the Columbia pebblesnail (also referred to as the Columbia River spire snail, Lithoglyphus columbianus) has a 1-year life cycle. Eggs are deposited during the spring as water temperatures begin to rise. This snail occurs on and under rocks and vegetation in slow to rapid currents of streams, and it has been reported from the Hanford Reach (DOE 1991). As a result of logging, grazing, farming practices, withdrawal of water for irrigation, and dam construction on the Columbia River and its tributaries, ma: $y$ streams and rivers no longer contain suitable habitat for the Columbia pebblesnail (DOE 1991). Because of the absence of streams in the 200 -W'est A rea, this species would not occur in the potential project area.

\subsubsection{Columbia Yellow-Cress (Rorripa columbiae) - C2 Status}

The columbia yellow-cress, a member of the mustard family, is a low-growing herb found in small scattered patches, along wet shorelines and islands of the Columbia River in Benton and Skamania counties. Washington (DOE 1991). No systematic surveys have been conducted to determine the status of this species on the Hanford site. However, it is not expected to be present in the 200-West Area because of the absence of suitable habitat. 


\section{EFFECTS OF PROPOSED ACTION AND ALTERNATIVES ON SPECIES AND HABITATS}

\subsection{ALTERNATIVE 1: NO ACTION}

Currently contaminated habitats at the chemical plant area total about 88 ha ( 217 acres). Under Alternative 1, potential exposure of some listed species and other biota to the contaminants would continue as a result of (1) direct exposure to contaminated media at existing source areas, (2) exposure of listed species to contaminants via food chain transport, and (3) inovement of contaminated groundwater and surface water to areas currently unaffected by site contaminants.

No designated critical habitat for the bald eagle occurs at the site or at any of the off-site source areas. The bald eagle occurs in the area but has never been reported from the site and is not expected to frequent the site because of the absence of suitable habitat. This species might occasionally feed on fish from Lakes 34,35 , and 36 in the Busch Wildlife Area and thus could potentially be exposed to contaminants at these locations via food chain transfer. The bald eagle may also feed on waterfowl (Kozie and Anderson 1991), and food chain transfer of contaminants from waterfowl to the bald eagle (at other locations) has been previously reported in the literature (Pattee and Hennes 1983). If contaminant biouptake and bioaccumulation are occurring in waterfowl using the contaminated on-site surface waters, the bald eagle could be affected by foraging on contaminated waterfowl. Under the no-action alternative, the potential for this contaminant pathway to affect the bald eagle would continue. A similar potential exists, and would continue to exist, for food chain transfer of contaminants to the bald eagle from ingestion of contaminated carrion or hunter-killed game, such as raccoon, pheasant, turkey, and rabbit (Craig 1990); from ingestion of contaminated media such as surface water; or from absorption across body surfaces.

The interior least tern could potentially be affected by contaminants present in the sediment of some off-site lakes. This species could be exposed while foraging in contaminated areas for small fish and insects, through direct dermal contact and/or ingestion of contaminated media, and through food chain transfer from prey inhabiting contaminated sediment. Because of the infrequent occurrence of this species in the area and the apparent absence of bioupirke of contaminants in off-site biota, as indicated by studies conducted to date (DOE 1992c), few or no impacts are anticipated to this species. However, under Alternative 1, the potential for contaminant exposure of and adverse effects to the interior least tern would continue.

The peregrine falcon might be exposed through food chain transfer to site contaminants by feeding on other bird species that utilize the chemical plant area for foraging, nesting, and roosting (e.g., starling, pigeon, and house sparrow). The transient nature of the peregrine falcon in the area suggests a very limited contaminant exposure potential for this species, but this limited exposure potential would continue under the no-action alternative.

The pallid sturgeon, sicklefin chub, and sturgeon chub have been reported from the Missouri River and could be exposed to contaminants from the Southeast Drainage. Neither the 
occurrence of these species in the Missouri River in the vicinity of the Southeast Drainage, nor the concentrations of all contaminants in the Missouri River at this location, are known. The pallid sturgeon and the sicklefin and sturgeon chubs are restricted to large rivers and are not expected to enter the Southeast Drainage. Thus, these species are not expected to be directly exposed to the contaminants in this drainage. These species might, however, be exposed to contaminated sediment and surface water entering the Missouri River from the Southeast Drainage (e.g., during storm events), and under Alternative 1 the potential for such exposure would continue. Similarly, the bald eagle is not expected to utilize the Southeast Drainage directly but might forage at or near its mouth and thus be exposed to site contaminants entering the river.

Under current conditions, only a very limited contaminant exposure potential is expected for the pallid sturgeon, sicklefin and sturgeon chubs, and baid eagle. Upstream and downstream uranium concentrations have been reported to range from 2.0 to $7.48 \mathrm{pCi} / \mathrm{L}$ and 2.0 to $9.52 \mathrm{pCi} / \mathrm{L}$, respectively (MKK-Ferguson Company and Jacobs Engineering Group 1990, 1991, 1992a), whereas the naximum reported surface water concentration within the Southeast Drainage is $1,200 \mathrm{pCi} / \mathrm{L}$. These data suggest that dilution within a short distance downstream of the inflow of the Southeast Drainage will greatly reduce the surface water concentrations of any contaminants entering the Missouri River from the drainage and thus reduce the potential for adverse affects to the listed biota and other species that might be present.

The radiation dose to freshwater fish from exposure to contaminated water and sediment at the confluence was estimated with conservative assumptions (Monette 1992; DOE, 1992a): (1) the radionuclides in each series are in secular equilibrium, (2) the energy liberated by each decay series within tissues is totally absorbed by the organism, (3) radioactive contaminants are distributed homogeneously within tissues, (4) organisms are continuously exposed to the maximum radionuclide concentration reported in water samples from each water body, and (5) all measurements below analytical detection limits are equal to the detection limit. Using these assumptions, the resulting estimated dose to fish (such as the pallid sturgeon) is less than the limit of $1 \mathrm{rad} / \mathrm{d}$ specified in DOE Order 5400.5 for the protection of native aquatic organisms.

\subsection{ALTERNATIVE 6a: REMOVAI, CHEMICAL STABILIZATION/ SOLIDIFICATION, AND DISPOSAL ON-SITE}

The removal of contaminated soil, surface water, sediment, and vegetation at the chemical plant area would prevent the future exposure of biota to contaminated media. Some permanent loss of wildlife habitat would result from the implementation of this alternative; however, no designated critical habitats for any of the listed, candidate, or review species would be disturbed. Excavation of contaminated source areas would disturb approximately 55 ha (137 acres) on-site and fewer than 2 ha ( 5 acres) at the off-site areas. Following completion of all remedial activities under this aiternative, permanent loss of habitat would be limited to the disposal cell area of approximately 17 ha ( 42 acres). 
Potential impacts to local biota could occur under Alternative $6 \mathrm{a}$ as a consequence of (1) excavation of contaminated source areas, (2) construction and operation of the treatment and volume reduction facilities, and (3) construction and operation of the disposal cell. Excavation activities at the site are not expected to impact any endangered, threatened, or $\mathrm{C} 2$ species because no listed or $\mathrm{C} 2$ species are known to exist in or utilize the source areas. Similarly, no impacts to listed or $\mathrm{C} 2$ species are anticipated from the construction and operation of the treatment and volume reduction facilities or the disposal cell. No construction or excavation activities would either occur in or affect habitats in the Missouri River in any way; thus, no impacts to the pallid sturgeon, sickelfin chub, and sturgeon chub are anticipated under Alternative 6a. In addition, any impacts associated with excavation and construction activities would be temporary. Good engineering practices and appropriate initigative measures would be used during all excavation and construction activities to prevent or minimize potential erosion, dust emissions, and contaminant releases.

Remedial action activities at the site could potentially disturb overwintering bald eagles using the Howell Island Wildlife Area as a roost site. However, such impacts are expected to be minimal because the distance from the chemical plant to Howell Island is approximately $3,200 \mathrm{~m}(10,600 \mathrm{ft})$ and the response of bald eagles to human activities has been shown to be strongly and inversely related to distance. Grubb and King (1991) assessed the effects of human disturbance on breeding bald eagles and reported the following median distances that evoked response from human disturbance: $300 \mathrm{~m}(980 \mathrm{ft}$ ) resulted in an "awareness" or alert response, $150 \mathrm{~m}(490 \mathrm{ft})$ resulted in a short distance flight, and $100 \mathrm{~m}(330 \mathrm{ft})$ caused departure from the immediate area of human activity. Grubb and King (1991) suggested that vehicles be excluded within at least $450 \mathrm{~m}(1,500 \mathrm{ft})$ and restricted within $850 \mathrm{~m}(2,800 \mathrm{ft})$ of breeding eagles. The distance from the chemical plant area to Howell Island is about 32 times greater than the minimum median distance reported by Grubb and King (1991) to prompt the departure of bald eagles from an area of human activity, 10 times greater than the median distance that evoked an alert response, and almost 4 times greater than the distance recommended for vehicle restrictions. Thus, human activities at the chemical plant area are not expected to disturb overwintering bald eagles at Howell Island. In addition, many of the types of pedestrian activities shown to affect eagle behavior - such as walking, hiking, hunting, and fishing (Grubb and King 1991) - are typical of visitors to the Weldon Spring and Howell Island wildlife areas.

Potential impacts to local biota (including listed and C2 species) could occur if the cell failed and no corrective measures were taken to prevent the release of contaminants to the environment. A monitoring well system would be installed to allow for the prompt detection of any localized releases from the disposal cell, and contingency plans would be developed and would be applied to rapidly address any releases. A leachate collection and removal system in the disposal cell would provide additional monitoring of the disposal cell and early detection of potential leachate migration. In addition, concentrations of some of the contaminants in the leachate from the treated materials would be below the criteria used to determine whether a waste is a characteristic hazardous waste (Table 4). Thus, impacts to listed species (and other biota) would be minimized in the event of a release of contaminants or leachate from the disposal cell. 
TABLE 4 Estimated Leachate Concentrations for Chemically Stabilized/Solidified Sludge and Quarry Soil ${ }^{a}$

\begin{tabular}{|c|c|c|c|}
\hline \multirow[b]{2}{*}{ Contaminant } & \multicolumn{2}{|c|}{$\begin{array}{c}\text { Estimated Leachate } \\
\text { Concentration } \\
(\mathrm{mg} / \mathrm{L})\end{array}$} & \multirow{2}{*}{$\begin{array}{c}\text { Maximum Leachate } \\
\text { Concentration } \\
\text { Allowed } \\
(\mathrm{mg} / \mathrm{L})\end{array}$} \\
\hline & $\begin{array}{l}\text { Raffinate Pit } \\
\text { Sludge }{ }^{\mathrm{b}}\end{array}$ & $\begin{array}{l}\text { Quarry } \\
\text { Soil }\end{array}$ & \\
\hline Arsenic & 0.218 & $<0.013$ & 5.0 \\
\hline Barium & 10.9 & 0.669 & $10(0.0$ \\
\hline Cadmium & $0 .(0)(33$ & $<(0.01) 2$ & 1.0 \\
\hline Chromium & 0.126 & 0.0182 & 5.0 \\
\hline Lead & $<0 .(1) 18$ & $<0.1) 18$ & $5.1)$ \\
\hline Mercury & $<0.0(x \times 12$ & $<0 .()(x) 4$ & $(0.2$ \\
\hline Selenium & (1).061 & $<1) .019$ & 1.0 \\
\hline Silver & 0.012 & $<1) .0(14$ & 5.0 \\
\hline NB & $<(0 .() 20$ & (0.813 & 2.0 \\
\hline 2,4-DNT & $<0 .(120)$ & 0.017 & 0.13 \\
\hline
\end{tabular}

a Concentrations in leachate are based on toxicity characteristic leachate procedure (TCLP) testing of raffinate pit sludge spiked with the historical high concentrations of contaminants and quarry soil spiked with the historical high concentration of nitrobenzene. Samples were stabilized/ solidified using the blend formula determined by Gilliam and Francis (1989) and cured for 28 days.

b Sludge samples were taken from each pit. The highest leachate concentration is reported here.

c TCLP limits; see Appendix G, Table G.3 of the FS (DOE 1992b).

Source: Waste Technologies Croup (1992).

Under a scenario that assumes future loss of institutional controls and failure of the disposal cell cover without corrective measures, contaminants could be dispersed to the environment as a result of transport from the cell by wind or water (rain). However, prior to placement in the disposal cell, the most highly contaminated material would have been treated by chemical stabilization/solidification, thereby decreasing the mobility of the contaminants and increasing the resistance of the material to degradation and transport by wind or water.

Positive impacts to listed and $C 2$ species would be incurred as a result of the removal, treatment, and disposal of the contaminated materials under Alternative 6a. Excavation of the source areas would romove the contaminated material from direct exposure to the environment, and chemical stabilization/solidification would reduce contaminant mobility. In addition, the site wastes would be isolated from the environment by containment in an engineered disposal cell, which would further limit contaminant mobility. 


\subsection{ALTERNATIVE 7a: REMOVAL, VITRIFICATION, AND DISPOSAL ON-SITE}

Impacts to biota under Alternative 7a would be similar in nature, magnitude, and duration to those identified for Alternative 6a; impacts would result primarily from excavation and construction activities, and treatment of contaminated materials. Alternative 7a would be similar to Altemative ba because the same source areas would be excavated and similar on-site areas would be temporarily disturbed by construction activities. The excavation of source areas would disturb approximately 55 ha (137 acres) on-site and less than 2 ha ( 5 acres) at the off-site areas, and permanent loss of habitat would be limited to the disposal cell area of approximately 17 ha (42 acres). As for Alternative 6a, excavation, construction, and treatment activities under Alternative $7 \mathrm{a}$ are not expected to disturb any listed species. Because of the distance of the Howell Island bald eagle winter roost area to the chemical plant, no disturbance of bald eagles from human activities at the Weldon Spring site is anticipated. No construction or excavation activities would occur in or affect habitats in the Missouri River in any way; thus, no impacts to the pallid sturgeo:n, sickelfin chub, and sturgeon chub are anticipated under Alternative 7a.

Good engineering practices and appropriate mitigative measures would be used during all excavation and construction activities to prevent or minimize potential erosion, dust emissions, and contaminant releases. No impacts to local biota are anticipated from off-gas releases during contaminant vitrification. The off-gas treatment system would consist of air pollution treatment and control devices (such as scrubbers and HEPA filters) and would be used at all times during vitrification.

Alternative 7a would result in the temporary disturbance of about $13,000 \mathrm{~m}^{2}$ $\left(140,000 \mathrm{ft}^{2}\right)$ of land along a 5.3-km $(3.3-\mathrm{mi})$ route in the Weldon Spring Wildlife Area that would not be disturbed under Alternative 6a. This land is necessary for a natural gas pipeline that would be constructed to fuel the vitrification process. Construction of the pipeline, which would parallel State Route 94 (Figure 3), could temporarily disturb habitat used by the loggerhead shrike, a C2 species that occurs at the wildlife area and has been observed in the vicinity of the proposed pipeline (Thomas 1992). This area may also be used by Bachman's sparrow, although no sightings of this species have been reported along the proposed pipeline area. Impacts to these species, if any, would primarily result from construction noise and human activity. However, because of the close proximity of State Route 94, this area receives considerable traffic and human activity. Thus, the potential temporary impacts from the pipeline construction are expected to be minor and not result in any adverse effects to either the loggerhead shrike or Bachman's sparrow. Following completion of the pipeline, the disturbed areas would be restored to original contours and revegetated.

As for Alternative 6a, a monitoring well system and a leachate collection and removal system would be installed to allow for the detection of any localized releases or leachate migration from the disposal cell. Contingency plans would be developed and in place to rapidly address any releases. In addition, concentrations of some of the contaminants in the leachate from the treated materials would be below the criteria used to determine whether a waste is a characteristic hazardous waste (Table 5). Under a scenario that assumes loss of institutional 
TABLE 5 Estimated Leachate Concentrations for Vitrified Sludge and Site Soil

\begin{tabular}{|c|c|c|c|}
\hline \multirow[b]{2}{*}{ Contaminant } & \multicolumn{2}{|c|}{$\begin{array}{l}\text { Estimated Leachate } \\
\text { Concentration } \\
(\mathrm{mg} / \mathrm{L})\end{array}$} & \multirow{2}{*}{$\begin{array}{l}\text { Maximum Leachate } \\
\text { Concentration } \\
\text { Allowed } \\
(\mathrm{mg} / \mathrm{L})\end{array}$} \\
\hline & ISV Glass & JHCM Glass & \\
\hline Arsenic & $<1$ & $<1$ & 5.0 \\
\hline Barium & 0.04 & 0.04 & $10(0.0$ \\
\hline Cadmium & 0.01 & $<0 .(01$ & 1.0 \\
\hline Chromium & $<1$ & $<1$ & $5 .()$ \\
\hline Lead & $<1$ & $<1$ & $5.1)$ \\
\hline Mercury & $<0 .(1) 3$ & $<0 .() 3$ & 0.2 \\
\hline Selenium & $<0.01$ & $<0.01$ & 1.0 \\
\hline Silver & $<() .1$ & $<() .1$ & $5.1)$ \\
\hline
\end{tabular}

a Concentration determined from a previous study of raffinate pit sludge and site soil with a modified extraction procedure (EP) toxicity test; further testing (TCLP) of similar waste to be conducted at other DOE facilities within the next several years will provide additional leachability data for vitrification. ISV = in-situ vitrification; $\mathrm{JHCM}=$ joule-heated ceramic melting.

b TCLP limits; see Appendix G, Table G.3 of the FS (DOE 1992b).

Source: Koegler et al. (1989).

controls and failure of the disposal cell cover, contaminants could be dispersed to the environment as a result of transport from the cell by wind or water (rain). However, prior to placement in the disposal cell, the most highly contaminated material would have been vitrified, thereby destroying some contaminants, decreasing the mobility of all remaining contaminants, and increasing the resistance of the material to degradation and transport by wind or water.

Alternative $7 \mathrm{a}$ would result in the same positive environmental impacts as those identified for Alternative 6a. Vitrification would destroy organic contaminants in some of the treated material and would result in a significant reduction in contaminant mobility. As with the chemically treated waste product, contaminant concentrations in leachate from the vitrified materials would be below the criteria used to determine whether a waste is a characteristic hazardous waste (Table 5). The site wastes would be isolated from the environment by containment in an engineered disposal cell, which would further limit contaminant mobility. Off-gas emissions from the vitrification process could potentially increase impacts to local biota (including some listed and C2 species). However, impacts are expected to be minimal because extensive off-gas controls (scrubbers and HEPA filters) would be used. 


\subsection{ALTERNATIVE 7b: REMOVAL, VITRIFICATION, AND DISPOSAL AT THE ENVIROCARE FACILITY}

Impacts to listed species could result from four sources: (1) excavation, construction, and treatment activities at the Weldon Spring site; (2) construction and operation of a rail siding at Wentzville; (3) construction and operation of a dispusal cell at the Envirocare facility; and (4) transfer of contaminated media from the railcars to the disposal cell. Excavation, construction, and treatment activities at the Weldon Spring site under Alternative $7 \mathrm{~b}$ would be similar in nature, magnitude, and duration to those identified for Alternative 7a. In addition, although no disposal cell would be constructed on-site under this alternative, an area similar to that targeted for the cell under Alternative 7a would be temporarily disturbed because site structures and other contaminant sources would be removed from that location and it would then be used as the staging area to support waste transport off-site. Implementation of Alternative $7 \mathrm{~b}$ would also require the construction of a rail siding in Wentzville, Missouri. No federal-listed species occur in the area, and none would be expected to be impacted by the construction and operation of the rail siding.

Construction of a disposal cell at the Envirocare facility would destroy approximately 17 ha (42 acres) of semidesert shrubland (shadscale and gray molly). No wetlands or floodplains occur at the site. Existing vegetation and some wildlife at the site would be destroyed, other wildlife using the area would be permanently displaced, and wildlife in nearby areas would be temporarily disrupted during cell construction. Waste-handling activities (unloading waste containers at the rail siding and transporting containers to the disposal cell) would result in only an incremental increase in disturbance to local wildlife from human activities.

No impacts to the bald eagle and peregrine falcon are anticipated from activities at the Envirocare facility. No designated critical habitat, roost sites, or nesting areas exist at, or in the vicinity of, the Envirocare facility. Two peregrine falcon hack sites are located $42 \mathrm{~km}(26 \mathrm{mi}$ ) east and $88 \mathrm{~km}(55 \mathrm{mi})$ northeast of the facility. Because of the distances from the Envirocare facility to these areas, no impacts are anticipated to peregrine falcons at these hack sites.

Disturbance to bald eagles from activities at the Envirocare facility is expected to be minor. The bald eagle is known to winter in Skull Valley and Rush Valley, $24 \mathrm{~km}$ (15 mi) and $48 \mathrm{~km}(30 \mathrm{mi})$, respectively, east of the Envirocare facility. These distances are more than 200 times greater than the 100-m (330-ft) distance from human activity reported by Grubb and King (1991) to prompt departure by eagles from the immediate area. These distances are also 80 and 160 times greater, respectively, than the median distances reported for human activities to evoke an alert response by bald eagles and more than 25 times greater than the distance recommended for vehicle restrictions to minimize bald eagle disturbance (Grubb and King 1991).

Given the possibility of lengthy foraging trips by the bald eagle and peregrine falcon, individuals could potentially forage in the vicinity of the proposed disposal cell and be exposed to the treated materials; also, the construction of the disposal cell could eliminate approximately 17 ha (42 acres) of foraging area for these species. The impacts from exposure and loss of foraging area would be minimized because (1) current and future activities at the Envirocare facility will likely preclude the use of the immediate surroundings by the eagle or peregrine 
falcon, (2) many of the Weldon Spring contaminants would be physically bound in a vitrified product and have a very low mobility potential, and (3) the vitrified and untreated materials would be isolated from the environmeni by placement in an engineered disposal cell.

The Envirocare facility is currently operational, and waste handling, waste storage, and environmental monitoring are occurring at the site. The facility includes transfer and storage areas, decontamination facilities, and a laboratory. The current monitoring program at the Envirocare facility includes sampling of about 10 of 42 wells located around the currently existing disposal cell. Samples are routinely analyzed for contaminants that are representative of the waste types present in the cell. Similar activities would be expicted for monitoring the containment effectiveness of the Weldon Spring waste.

Cell failure or the spill of a waste container during delivery to and handling at the site could cause the release of vitrified material or less contaminated material. The site is currently active in waste handling and disposal, and emergency spill and cleanup procedures are already in place; additional contingency plans might be developed for the Weldon Spring waste. In addition, the site has decontamination facilities, an analytical laboratory, and monitoring and maintenance programs. It is assumed that a leachate collection and removal system in the disposal cell would provide additional monitoring of the disposal cell integrity and early detection of potential leachate migration. In addition, the contaminant mobility from the vitrified product is extremely limiled, and contaminant concentrations in leachate from the vitrified product would be very low (Table 5). In the event of cell failure, rapid implementation of contingency procedures would be expected to limit the release of contaminants to the environment. The Union Pacific Railroad, which owns the rail line that would be used to deliver contaminants to the Envirocare facility, employs hazardous waste emergency response teams throughout its system. Information pertinent to shipment of the Weldon Spring waste (e.g., waste characteristics and emergency handling information) would be entered into the railroad computer system for access hy the emergency response teams, if needed. A spill contingency plan would be developed and, in the event of a spill, an emergency response team would reload the spilled material, test the area for residual contamination, and clean the area as needed. Thus, potential impacts to listed species (and other biota) would be minimized in the event of an accidental release of contaminants or leaching from the disposal cell.

\subsection{ALTERNATIVE 7c: REMOVAL, VITRIFICATION, AND DISPOSAL AT THE HANFORD FACILITY}

Impacts resulting from activities at the Weldon Spring chemical plant area and at the Wentzville rail siding would be the same for Alternative $7 \mathrm{c}$ as Alternative $7 \mathrm{~b}$. The amount of land area impacted at the 200-West Area of the Hanford facility was assumed to be the same as at the Envirocare facility (and the Weldon Spring site). About 17 ha (42 acres) of vegetation and wildlife habitat (sagebrush/cheatgrass or Sandberg's bluegrass) would be permanently destroyed. Construction and maintenance of a disposal cell at the 200-West Area would have little effect on listed species in the area because (1) the construction activities would be

temporary, (2) the appropriate breeding and foraging habitats for the listed species do not occur 
in the 200-West Area, and (3) the vitrified and untreated materials would be isolated from the environment in an engineered disposal cell.

The bald eagle is a winter resident at the Hanford facility and forages and roosts along the Columbia River, about $8 \mathrm{~km}$ (5 mi) from the 200-West Area; no known nests or territories occur at the Hanford site (DOE 1991). Although no inland surveys have been conducted for bald eagles at the site, it is unlikely to occur far from the river, especially during winter when few prey would be available in the 200-West Area. In addition, the shrub-steppe habitat present at the 200-West Area is not expected to provide suitable nesting or roosting habitat (large trees) for this species. Human activities in the 200-West Area associated with cell construction and maintenance and other activities would further limit the likelihood of the bald eagle foraging in the area of the disposal sll.

Disturbance to bald eagles along the Columbia River from construction and disposal activities at the 200-West Area is expected to be slight. The distance from the Columbia River to the 200-West Area is approximately $8 \mathrm{~km}(5 \mathrm{mi})$, which is about 80 times greater than the $100-\mathrm{m}(330-\mathrm{ft})$ distance from human activity reported to prompt departure by eagles from the immediate area and more than 25 times greater than the median distance reported for human activities to evoke an alert response by bald eagles (Grubb and King 1991). Thus, construction and disposal activities at the 200-West A rea are not expected to affect wintering bald eagles along the Columbia River.

No inland surveys of the 200-West Area have been conducted for the peregrine falcon. The peregrine falcon, a transient migrant, would be expected to forage near and along the Columbia River and to avoid the disposal cell area because of human activity. Furthermore, this species is not expected in the area during the summer when cell construction would occur. At the Hanford facility, the western sage grouse (C2) population is small and appears to be confined entirely to the slopes of the Rattlesnake Hills (Pacific Northwest Laboratory 1991), about $8 \mathrm{~km}$ (5 mi) south of 200-West Area. The construction and maintenance of a disposal cell at the 200-West Area is not expected to impact these birds because of the distance involved.

The ferruginous hawk (C2) could be impacted by the conversion of 17 ha (42 acres) of shrub-steppe habitat. Loss of this habitat type has been cited as one factor contributing to the decline of ferruginous hawk populations (DOE 1991). Because no recent surveys have been conducted for this species, its present status at the Hanford site in general, and at the 200-West Area in particular, is not known. Columbia yellow-cress (C2) occurs in wet areas along the Columbia River. The 200-West Area is primarily shrub-steppe habitat with little or no surface water present. Thus, there appears to be no suitable habitat for this species in the 200-West Area, and the Columbia yellow-cress would not be expected to occur at this location (DOE 1991). The loggerhead shrike may occur in the 200-West Area (Pacific Northwest Laboratory 1991) and could be temporarily disturbed by construction and waste disposal activities. Disturbance due to construction noise and human activity would be temporary and cease following closure of the disposal cell. Construction of a disposal cell would destroy approximately 17 ha (42 acres) of shrub-steppe habitat that could be used by this species for nesting and foraging. 
Three $\mathrm{C} 2$ species identified as potentially occurring at the Hanford site - the bull trout, California floater, and Columbia pebblesnail - are aquatic species confined to the Columbia River. Consequently, they would not be affected by the construction of a disposal cell at the 200-West Area or by disposal activities at this location. No marshes or meadows occur in the 200-West Area and, in the absence of these habitats or other surface waters, the black tern (C2) is not expected to occur in the area or be impacted by cell construction and waste disposal activities.

Cell failure or the spill of a waste container during delivery to or handling at the site could cause the release of vitrified material or less contaminated materials. Spill contingency plans would be expected to be in place to address accidental spills or cell failure and, in the event of cell failure, rapid implementation of emergency procedures would be expected to limit the release of contaminants to the environment. In addition, the contaminant mobility from the vitrified product is extremely limited and, with prompt cleanup, an accidental spill of such material would pose little, if any, threat to biota (listed or not). A monitoring well system would be in place to detect any localized releases from the disposal cell, and contingency plans would have been developed and in place to rapidiy address any releases. It is assumed that a leachate collection and removal system in the disposal cell would provide additional monitoring of the disposal cell integrity and early detection of potential leachate migration. In addition, the contaminant mobility from the vitrified product is extremely limited and contaminant concentrations in leachate from the vitrified product would be very low (Table 5). Thus, impacts to listed species (and other biota) would be minimized in the event of an accidental release of contaminants or leaching from the disposal cell. 


\section{MITIGATION AND MONITORING}

Mitigative measures that would be used at the Weldon Spring site in implementing any of the final action alternatives $(6 a, 7 a, 7 b$, and $7 c)$ are summarized in Table 6 . These measures would provide a high degree of effectiveness in minimizing the potential for adverse environmental effects associated with the excavation, construction, hauling, and treatment activities that would occur at the site. For activities related to the construction, operation, and closure of a disposal cell, it is expected that similar measures would be implemented at the off-site facilities.

Mitigative measures for protecting air quality - such as wetting surfaces, using chemical dust suppressants, and covering stockpiles and loads during transportation - would be implemented to control fugitive dust. The off gas generated during the vitrification process would be collected and treated. Air quality would be intensively monitored for all action alternatives to assess compliance with all pertinent air quality standards and ensure that appropriate controls could be applied in a timely manner, if needed.

Mitigative measures and good engineering practices would be used in all excavation and construction areas to control surface water runoff, erosion, and transport of sediment or contaminants from exposed areas. These measures would include using silt fences and straw bales downstream of work areas, covering stockpiles and exposed areas, constructing siltation ponds, and constructing berms to ssolate work areas and direct the surface flow of water. All runoff from contaminated areas would be retained in siltation ponds, sampled for contamination, and treated in the site water treatment plant before release, if necessary.

Groundwater at the Weldon Spring site would be monitored before, during, and after remedial action activities. If adverse effects to groundwater were detected, appropriate contingency plans would be implemented.

Waste for off-site disposal would he transported in closed containers and carried in dedicated trains to the disposal location. Contingency plans would be in place to address spills that might occur during any phase of off-site transport. Both haul vehicles and the exteriors of the containers would be decontaminated and inspected before leaving any contaminated area. Potential impacts from off-site accidental spills would be minimized by rapidly implementing appropriate operating procedures and contingency plans.

Following completion of all construction and excavation activities, disturbed areas on-site would be backfilled and revegetated, and disturbed areas outside the site boundary would be restored to natural conditions. Habitat restoration would be carried out in consultation with appropriate state and federal agencies.

Site cleanup activities would be conducted in compliance with the site safety and health plans, DOE safety regulations, and other pertinent requirements. Prior to implementing the selected remedy, detailed plans would be provided to address (1) accidental contaminant releases to the environment, (2) emergency response procedures, (3) monitoring techniques and frequencies, and (4) various contingencies and the anticipated responses to such contingencies. 
TABLE 6 Major Monitoring and Mitigative Measures for the Action Alternatives

\begin{tabular}{|c|c|c|}
\hline Factor & $\begin{array}{l}\text { Potential Impact or } \\
\text { Area of Concern }\end{array}$ & Mitigative Measure \\
\hline \multirow[t]{2}{*}{$\begin{array}{l}\text { Construction and } \\
\text { excavation activities }\end{array}$} & $\begin{array}{l}\text { Transport of uncontami- } \\
\text { nated soil to nearby } \\
\text { surface water and } \\
\text { wetlands }\end{array}$ & $\begin{array}{l}\text { Good construction practices would be implemented, } \\
\text { including sediment barriers, dikes, siltation ponds, } \\
\text { and drainage channels to direct runoff away from } \\
\text { downstream or downgradient surface waters and } \\
\text { wetlands, with surface grading and revegetation } \\
\text { upon completion of excavation. }\end{array}$ \\
\hline & $\begin{array}{l}\text { Transport of contami- } \\
\text { nated surface soil to } \\
\text { nearby surface water and } \\
\text { wetlands, runoff of } \\
\text { contaminated surface } \\
\text { water, and possible } \\
\text { impacts of leaching of } \\
\text { contaminants to }\end{array}$ & $\begin{array}{l}\text { Good construction practices would be implemented, } \\
\text { as described above. In addition, groundwater, } \\
\text { surface runotf, surface water, and rediment would } \\
\text { continue to be monitored for chemical and } \\
\text { radioactive contaminants or that contaninated } \\
\text { media would be collected for subsequent } \\
\text { management, including treatment ot any } \\
\text { contaminated water betore release off-site. }\end{array}$ \\
\hline
\end{tabular}

Loss of aquatic and terrestrial habitats

Disturbance of local biota, area residents, and recreational visitors by noise and remedial action activities

Disturbance of local biota, area residents, and recreational visiturs and impacts to local air quality as a result of fugitive dust emissions

Radon and particulate emissions

Accidental spill (release) of contaminated material as a result of equipment failure or vehicular accident
Habitats would be restored, as appropriate. The final form of mitigation would be determined in consultation with appropriate state and federal agencies.

Vehicle and equipment mufflers would be checked periodically and maintained in good condition.

Dust would be controlled using wet methods and/or covers at the site, along the haul roads, at storage and staging areas, and at off-site construction and excavation areas. Chemical dust suppressants would be used if needed. Work areas would be covered, as needed, e.g., at night and during high winds.

Engineering controls - such as reducing working surface areas and using covers, water, or chemical agents - would be applied, as needed, to reduce radon and particulate emissions. Air would be monitored continuously through all phases of the action period.

Waste would be transported in covered trucks traveling at low speeds. Contingency plans would be in place to address any spills that might occur during waste transport. vicinity properties to the site 
TABLE 6 (Cont.)

\begin{tabular}{|c|c|}
\hline Factor & $\begin{array}{l}\text { Potential Impact or } \\
\text { Area of Concern }\end{array}$ \\
\hline $\begin{array}{l}\text { Transport of contami- } \\
\text { nated material from } \\
\text { vicinity properties } \\
\text { to the site (cont.) }\end{array}$ & $\begin{array}{l}\text { Inadvertent transport of } \\
\text { contaminated material on } \\
\text { haul vehicle surfaces or } \\
\text { tires leaving controlled } \\
\text { areas }\end{array}$ \\
\hline \multirow[t]{3}{*}{$\begin{array}{l}\text { Excavation of off-site } \\
\text { borrow material }\end{array}$} & $\begin{array}{l}\text { Erosion of wil, with } \\
\text { transport to nearby } \\
\text { surtace water and } \\
\text { wetlands }\end{array}$ \\
\hline & $\begin{array}{l}\text { Disturbance of local biota, } \\
\text { area residents, and } \\
\text { recreational visitors by } \\
\text { noise }\end{array}$ \\
\hline & $\begin{array}{l}\text { Disturbance of local biota, } \\
\text { area residents, and } \\
\text { recreational visitors and } \\
\text { impacts to local air } \\
\text { quality as the result of } \\
\text { fugitive dust emissions }\end{array}$ \\
\hline $\begin{array}{l}\text { Transport of borrow } \\
\text { materials and supplies } \\
\text { to the site }\end{array}$ & $\begin{array}{l}\text { Inadvertent transport of } \\
\text { contaminated material } \\
\text { from the site on the haul } \\
\text { vehicle surfaces or tires }\end{array}$ \\
\hline \multirow[t]{2}{*}{$\begin{array}{l}\text { Transport of waste to an } \\
\text { off-site disposal location }\end{array}$} & $\begin{array}{l}\text { Accidental spill (release) } \\
\text { of contaminated material } \\
\text { as a result of equipment } \\
\text { failure or vehicular } \\
\text { accident }\end{array}$ \\
\hline & $\begin{array}{l}\text { Inadvertent transport of } \\
\text { contaminated material on } \\
\text { haul vehicle surfaces or } \\
\text { tires leaving controlled } \\
\text { areas }\end{array}$ \\
\hline
\end{tabular}

All phases of active remedial activities

\section{Mitigative Measure}

Haul vehicles would be decontaminated and inspected before leaving the site or off-site excavation areas.

Good construction practices would be implemented, including sediment barriers and siltation ponds, as needed.

Vehicle and equipment mufflers would be checked periodically and maintained in good condition.

Dust would be controlled using wet methods at the borrow area and along the haul road. Chemical dust suppressants would be used if needed.

Trucks hauling borrow material would not enter contaminated areas on the site.

Waste would be transported in closed containers. Contingency plans would be in place to address any spills that might uccur during waste transport.

Haul vehicles and containers would be decontaminated and inspected before leaving any contaminated areas.

All activities would be conducted in accordance with project health and safety plans and would include continuous monitoring of the work environment and the use of protective equipment, as needed. 
TABLE 6 (Cont.)

Fotential Impact or
Area of Concern

All phases of active remedial activities (cont.) public
Protection of the general

Environmental monitoring

Environmental restoration

Completion of all construction and excavation activities
Mitigative Measure

Air and water would be monitored at the site and vicinity, and appropriate responses would be implemented if measured contaminant levels increased significantly above background. Access to construction and excavation areas would be limited; public vehicle access would also be limited along some of the off-site haul routes. Dust, radon, noise, and erosion controls would be applied during remedial action activities. Decontamination methods would be employed to minimize vehicle tracking of contaminants to surrounding uncontaminated areas. All traffic associated with the remedial action would be coordinated to minimize impacts on nearby facilities.

Air quality would be monitored for contaminated particulates and radon gas at the site perimeter. Radon would also be monitored at the nearby Francis Howell High School. Surface water and groundwater downgradient of excavation and construction areas would be monitored for chemical and radioactive contaminants, including uranium. Groundwater would also be monitored at additional on-site and off-site locations, including the perimeter of the disposal cell area. Appropriate responses would be implemented as indicated by monitoring results.

Remedial action areas would be restored by regrading and revegetating with native and/or forage species. Wetlands would be constructed, as indicated, on the basis of consultation with the appropriate state and federal agencies.

Disposal site maintenance and cell integrity
An operations plan would be in place to ensure monitoring of long-term disposal cell integrity. This plan would include regular cell inspection and site vegetation control programs, handling and disposal of leachate, as well as groundwater, surface water, and air monitoring programs. Contingency plans would be developed to address any loss of disposal cell integrity and/or release of disposed materials. 


\section{CONCLUSIONS}

\subsection{ALTERNATIVE 1}

Under the no-action alternative, the potential for exposure of some listed and C2 species to the contaminants would continue as a result of (1) direct exposure to contaminated inedia at existing source areas, (2) exposure via food chain transport, and (3) movement of contaminated groundwater and surface water to areas currently unaffected by site contaminants.

\subsection{ALTERNATIVE 6a}

No adverse impacts to listed or C2 species are anticipated for Alternative 6a. Under this alternative, potential exposure of listed and $C 2$ species in the Weldon Spring area would be reduced or eliminated for several reasons. First, contaminated soil, sediment, and other materials would be removed from on-site and off-site areas. Second, the highly contaminated materials would undergo chemical stabilization/solidification', thereby reducing contaminant mobility. Last, the treated and untreated material would se isolated from the environment in an

engineered disposal cell. A program would be established to monitor contaminant containment in the cell, and appropriate contingency plans would be in place to rapidly address cell failure or contaminant release to the environment.

Potential impacts to local biota - primarily disturbance from excavation, construction, and disposal activities - would be temporary, and good engineering practices and appropriate mitigative measures would minimize the likelihood of short-term adverse impacts diring these activities. Because of the absence of listed and C2 species from the chemical plant area and affected off-site locations, few if any short-term impacts are expected to these biota from the remedial action activities. The distance from the chemical plant area to the nearest known bald eagle winter roost site would preclude individuals at that location from being adversely affected by activities at the site.

Remedial activities under Alternative 6a would result in the temporary loss of about 38 ha ( 94 acres) of habitat and the permanent loss of about 17 ha ( 42 acres) of habitat. None of these areas provide suitable or designated critical habitat for listed species, and no impacts to listed or $\mathrm{C} 2$ species from this habitat disturbance are expected. Excavation activities at the potential borrow area off-site could disturb the loggerhead shrike (C2) and Bachman's sparrow (C2) and could result in the permanent loss of potential nesting and foraging habitat for these species.

\subsection{ALTERNATIVE 7a}

Potential impacts to local biota under Alternative 7a are expected to be the same as those identified for Alternative 6a, and no impacts are anticipated to listed or C2 species. Potential exposure of listed and C2 species would be reduced because contaminated media would be removed, the highly contaminated material would be vitrified, and all contaminated 
materials would be isolated from the environment in an engineered disposal cell. In addition, the vitrification process would destroy some of the contaminants, thereby reducing the toxicity of the treated material. A program would be established to monitor contaminant containment in the cell, and appropriate contingency plans would be in place to rapidly address any cell failure or contaminant release to the enviromment.

Potential impacts to local biota - primarily disturbance from excavation, construction, and disposal activities - would be temporary, and good engineering practices and appropriate mitigative measures would minimize the likelihood of short-term adverse impacts during these activities. Potential impacts from exposure to off gas released during the vitrification process would be minimized through the use of an off-gas treatment system, including HEPA filters. Because no listed or C2 species occur at the chemical plant area and affected off-site locations, few if any short-term impacts are expected to these biota from the remedial action activities. Also, no disturbance to the bald eagle winter roost located on Howell Island is expected.

Remedial activities under this alternative would result in the temporary loss of about 38 ha (94 acres) of wildlife habitat, and the permanent loss of about 17 ha (42 acres) of habitat. None of these area provide suitable or designated critical habitat for listed species, and no impacts to listed or C2 species from this habitat disturbance are expected. Excavation activities at the potential borrow area off-site could disturb the loggerhead shrike (C2) and Bachman's sparrow (C2) and could result in the permanent loss of potential nesting and foraging habitat for these species.

\subsection{ALTERNATIVE 7b}

Potential impacts to local biota for Alternative $7 \mathrm{~b}$ are expected to be identical to those identified for Alternative $7 a$, and no impacts are anticipated to listed or C2 species. Potential impacts to local biota - primarily disturbance from excavation, construction, and disposal activities - would be temporary, and good engineering practices and appropriate mitigative measures would minimize the likelihood of short-term adverse impacts during these activities. Potential impacts from exposure to off gas released during the vitrification process would be minimized through the use of an off-gas treatment system, including HEPA filters. Because no listed or $\mathrm{C} 2$ species occur at the chemical plant area and affected off-site locations, few if any short-term impacts are expected to these biota from the remedial action activities. Also, no disturbance to the bald eagle winter roost located on Howell Island is expected, and no listed or $\mathrm{C} 2$ species occur in the area of the Wentzville rail siding.

Remedial activities under Alternative $7 \mathrm{~b}$ would result in the temporary loss of about 55 ha (136 acres) of wildlife habitat in the Weldon Spring area. No suitable or designated critical habitat for listed species occurs in these areas, and no impacts to listed or C2 species from this habitat disturbance are expected. Excavation activities at the potential borrow area off-site could disturb the loggerhead shrike (C2) and Bachman's sparrow (C2) and could result in the permanent loss of potential nesting and foraging habitat for these species. 
No impacts to the bald eagle or peregrine falcon are anticipated from the construction and operation of a disposal cell at the Envirocare facility. Bald eagle roost areas and peregrine falcon hack sites are distant enough that these species should not be affected by activities at the Envirocare facility. Construction of the disposal cell would result in the permanent loss of about 17 ha (42 acres) of semidesert shrubland and could eliminate some potential foraging habitat. Current activities associnted with the facility likely preclude use of the potential disposal cell area by either of these species.

A program would be in place to monitor the integrity of cell containment, and appropriate contingency plans would be in place to rapidly address cell failure or contimninant release to the environment. The impacts from accidental releases to the environment during transport would be minimized because the more highly contaminated material would be vitrified and contaminant mobility from the vitrified product is extremely limited. In addition, a Union Pacific Railroad hazardous response team would be informed of all rail transport of contaminated materials to the Envirocare facility, and this team would respond immediately to any accidental spills that might occur during transport.

\subsection{ALTERNATIVE 7c}

Potential impacts to local biota for Alternative $7 \mathrm{c}$ are expected to be identical to those identified for Alternative $7 \mathrm{~b}$, and no impacts are anticipated to listed or $\mathrm{C} 2$ species. Potential impacts to local biota from excavation, construction, and disposal activities would be short term, and good engineering practices and appropriate mitigative measures would minimize the likelihood of adverse impacts during these activities. Potential impacts from exposure to off-gas releases during the vitrification process would be minimized through the use of an off-gas treatment system, including HEPA filters. No disturbance to the bald eagle winter roost located on Howell Island is expected, and no listed or C2 species occur in the area of the Wentzville rail siding.

Remedial activities under this alternative would result in the temporary loss of about 55 ha (136 acres) of wildlife habitat in the Weldon Spring area. No suitable or designated critical habitat for listed species occurs in these areas, and no impacts to listed or C2 species from this habitat disturbance are expected. Excavation activities at the potential borrow area off-site could disturb the loggerhead shrike (C2) and Bachinan's sparrow (C2) and could result in the permanent loss of potential nesting and foraging habitat for these species.

Construction and maintenance of a disposal cell at the 200-West Area of the Hanford facility would have little effect on the listed and $C 2$ species in the area because (1) construction activities would be short term; (2) except for the loggerhead shrike (C2), no listed or C2 species are known from the 200-West Area; (3) little or no suitable habitat for listed or C2 species is present at this location; and (4) the treated and untreated materials would be isolated from the environment in an engineered disposal cell. The loggerhead shrike occurs in the area and cou'd be temporarily disturbed during construction and disposal activities. Construction of the disposal cell could eliminate about 17 ha (42 acres) of potential foraging and nesting habitat for this species, but loss of this area is not expected to result in a significant impact to this species.' 
A program would be in place to monitor the integrity of waste containment in the cell, and appropriate contingency plans would be in place to rapidly address cell failure or contaminant release to the environment. Accidental releases to the environment would be minimized. 


\section{REFERENCES}

Bent, A.C., 1968, Life Histories of North American Curdinals, Buntings, Towhees, Finches, Sparrows, and Allies - Order Passeriformes: Family Fringillidae - Part Two, Smithsonian Institution Press, Washington, D.C.

Benton, R., 1992, personal communication from R. Benton (U.S. Fish and Wildlife Service, Utah State Office, Salt Lake City, Utah) to I. Hlohowskyj (Environmental Assessment and Information Sciences Division, Argonne National Laboratory, Argonne, III.), Sept 23.

Brabander, J.J., 1990, letter from I.J. Brabander (Field Supervisor, U.S. Fish and Wildlife Service, Columbia Field Office, Columbia, Mo.) to I. Hlohowskyj (Environmental Assessment and Information Sciences Division, Argonne National Laboratory, Argonne, III.), May 9.

Brabander, J.J., 1991, letter from J.J. Brabander (Field Supervisor, U.S. Fish and Wildlife Service, Columbia Field Office, Columbia, Mo.) to I. Hlohowskyj (Environmental Assessment and Information Sciences Division, Argonne National Laboratory, Argonne, Ill.), June 27.

Brabander, J.J., 1992, letter from J.J. Brabander (Field Supervisor, U.S. Fish and Wildlife Service, Columbia Field Office, Columbia, Mo.) to I. Hlohowskyj (Environmental Assessment and Information Sciences Division, Argonne National Laboratory, Argonne, [II.), Oct. 1.

Carr, A., 1952, Handbook of Turtles: The Turtles of the United States, Canada, and Baja California, Comstock Publishing Association, Ithaca, N.Y.

Charbonneau, C., 1992, personal communication from C. Charbonneau (U.S. Fish and Wildlife Service, Columbia Field Office, Columbia, Mo.) to I. Hlohowskyj (Environmental Assessment and Information Sciences Division, Argonne National Laboratory, Argonne, Ill.), Sept. 29.

Craig, T.H., 1990, Lead Concentrations in Golden and Bald Eagles, Wilson Bulletin, 1()2(1):130-133.

Dickneite, D.F., 1988, letter from D.F. Dickneite (Planning Division Chief, Missouri Department of Conservation, Jefferson City, Mo.) to I. Hlohowskyj (Environmental Assessment and Information Sciences Division, Argonne National Laboratory, Argonne, III.), August 24.

Dickneite, D.F., 1991, letter from D.F. Dickneite (Planning Division Chief, Missouri Department of Conservation, Jefferson City, Mo.) to I. Hlohowskyj (Environmental Assessment and Information Sciences Division, Argonne National Laboratory, Argonne, III.), August 9.

Dieffenbach, B., 1990, letter from B. Dieffenbach (Assistant Environmental Administrator, Missouri Department of Conservation, Jefferson City, Mo.) to D. Reinhardt (Environmental Assessment and Information Sciences Division, Argonne National Laboratory, Argonne, (II.), with attachments, March 19. 
Dieffenbach, B., 1992, letter from B. Dieffenbach (Assistant Environmental Administrator, Missouri Department of Conservation, Jefferson City, Mo.) to S.H. McCracken (Project Manager, Weldon Spring Site Remedial Action Project, St. Charles, Mo.), July 27.

DOE: see U.S. Department of Energy.

Envirocare of Utah, Inc., 1991, Application for 11e(2) Radioactive Materials License, submitted April 22, 1991, to the Nuclear Regulatory Commission, Revision 1, Text.

Fairchild, J., 1991, letter from J. Fairchild (Habitat Manager, State of Utah Department of Natural Resources, Division of Wildlife Resources, Springvil!e, Utah) to C. Dum (Envirommental Assessment and Information Sciences Division, Argonne National Laboratory, Argonne, III.), with attachment, June 19.

Federal Insurance Administration, 1978, Flood Insurance Kate Map, St. Charles County, Missouri (Unincorporated Areas), community-panel number 2903150100 A, p. 100 of 350, U.S. Department of Housing and Urban Development, National Flood Insurance Program.

Figg, D.E., 1991, letter with attachment from D.E. Figg (Endangered Species Coordinator, Missouri Department of Conservation, Jefferson City, Mo.) to J.R. Powers (MK-Ferguson Company, St. Charles, Mo.), Nov. 26.

Flotlin, K., 1992, telecommunication from K. Flotlin (Endangered Species Specialist, U.S. Fish and Wildlife Service, Olympia, Wash.) to C.P. Dunn (Environmental Assessment and Information Sciences Division, Argonne National Laboratory, Argonne, III.), Sept. 24.

Gaines, E.P., 1988, letter from E.P. Gaines (Data Manager, Missouri Department of Conservation, Jefferson City, Mo.) to I. Hlohowskyj (Environmental Assessment and Information Sciences Division, Argonne National Laboratory, Argonne, III.), with attachments, Sept. 8.

Gilliam, T.M., and C.L. Francis, 1989, Weldon Spring Raffinate Pits: Evaluation of Cement-Based Grouts as a Stabilization Option, ORNL/TM-11260, prepared for U.S. Department of Energy, Oak Ridge Operations Office, Weldon Spring Site Remedial Action Project, St. Charles, Mo., lune.

Gloman, N.J., 1991, letter from N.J. Gloman (Acting Field Supervisor, U.S. Fish and Wildlife Service, Olympia, Wash.) to I. Hlohowskyj (Environmental Assessment and Information Sciences Division, Argonne National Laboratory, Argonne, III.), July 17.

Grubb, T.G. and R.M. King, 1991, Assessing Human Disturbance of Breeding Bald Eugles With Classification Tree Models, Journal of Wildlife Management, 55(3):500-511.

Hlohowskyj, I., 1990, personal observation of I. Hlohowskyj (Environmental Assessment and Information Sciences Division, Argonne National Laboratory, Argonne, (II.) at the Weldon Spring site. 
Johnson, C.D., 1991, letter from C.D. Johnson (Assistant Field Supervisor, U.S. Fish and Wildlife Service, Utah State Office, Salt Lake City, Utah) to I. Hlohowskyj (Environmental Assessment and Information Sciences Division, Argonne National Laboratory, Argonne, Ill.), July 2.

Johnson, T.R., 1987, The Amphibians and Reptiles of Missouri, Missouri Department of Conservation, Jefferson City, Mo.

Koegler, S.S., et al., 1989, Vitrification Technologies for Weldon Spring Raffinate Sludges and Contaminated Soils, Phase II Report: Screening of Alternatives, PNL-7125, prepared by Pacific Northwest Laboratory, Richland, Wash., for U.S. Department of Energy, Oak Ridge Operations Office, Weldon Spring Site Remedial Action Project, Nov.

Kozie, K.D., and R.K. Anderson, 1991, Productivity, Diet, and Environmental Contaminants in Bald Eagles Nesting near the Wisconsin Shoreline of Lake Superior, Archives of Envirommental Contamination and Toxicology, 2():41-48.

Landeen, D., 1992, relecommunication from D. Landeen (Wildlife Ecologist, Westinghouse Corp., Hanrord Site, Ricinland, Wash.) to C.P. Dumn (Environmental Assessment and Information Sciences Division, Argonne National Laboratory, Argonne, III.), Sept. 24.

Li, H.W., et al., 1987, Factors Influencing Changes in Fish Assemblages of Pacific Northwest Streams, in Commini.y and Evolutionary Ecology of North American Stream Fishes, W.J. Matthews and D.C. Heins (editors), University of Oklahoma Press, Norman, Okla., pp. 193-202.

MDOC: see Missouri Department of Conservation.

Miller, J., 1991, data provided by J. Miller (Herpetologist, Missouri Department of Conservation, August A. Busch Wildlife Complex, Weldon Spring, Mo.) to J. Herron (MK-Ferguson Company, St. Charles, Mo.), Nov. 6.

Missouri Department of Conservation, 1984, Rare and Endangered Species of Missouri, Jefferson City, Mo.

Missouri Department of Conservation, 1989, Area Management Plan for the August A. Busch Complex, Jefferson City, Mo.

Missouri Department of Conservation, 1991, A Checklist of Birds of the August A. Busch Memorial Wildlife Area, Weldon Spring, Missouri, Jefferson City, Mo.

MK-Ferguson Company and Jacobs Engineering Group, 1990, Annual Site Environmental Report 1989, DOE/OR/21548-129, Rev. 1, prepared for U.S. Department of Energy, Oak Ridge Operations Office, Weldon Spring Site Remedial Action Project, Weldon Spring, Mo., Nov. 
MK-Ferguson Company and Jacobs Engineering Group, 1991, Annual Site Environmental Report for Calendar Year 199(), DOE/OR/21548-193, Rev. 1, prepared for U.S. Department of Energy, Oak Ridge Operations Office, Weldon Spring Site Remedial Action Project, Weldon Spring, Mo., Sept.

MK-Ferguson Company and Jacobs Engineering Group, 1992a, Annual Site Environmental Report for Calendar Year 1991, DOE/OR/21548-283, Rev. 1, prepared for U.S. Department of Energy, Oak Ridge Operations Office, Weldon Spring Site Remedial Action Project, Weldon Spring, Mo., July.

MK-Ferguson Company and Jacobs Engineering Group, 1992b, Engineering Analysis of Remedial Action Alternatives, Phase II, DOE/OR/21548-270, Rev. 0, prepared for U.S. Department of Energy, Oak Ridge Operations Office, Weldon Spring Site Remedial Action Project, Weldon Spring, Mo., Nov.

Monette, F.A., 1992, Daily Doses to Fish in Weldon Spring Surface Waters, interoffice memorandum from F.A. Monette to M.M. MacDonell (Environmental Assessment and Information Sciences Division, Argonne National Laboratory, Argonne, III.), with attachment, April 21.

Neitzel, D., 1992, personal communication from D. Neitzel (Biologist, Pacific Northwest Laboratory, Hanford, Wash.) to C.P. Dunn (Environmental Assessment and Information Sciences Division, Argonne National Laboratory, Argonne, (II.), Oct. 1.

Pacific Northwest Laboratory, 1991, Characterization of the Hanford Site and Environs, Pacific Northwest Laboratory, PNL-7668, prepared for U.S. Department of Energy, Richland, Wash.

Page, L.M., and B.M. Burr, 1991, A Fielu' Gliut io Freshwater Fishes, Hiougition Mifflin Company, Boston, Mass.

Pattee, O.H., and S.K. Hennes, 1983, Bald Eagles and Waterfowl: The Lead Shot Connection, Transactions of the North American Wildlife and Natural Resources Conference, 48:230-237.

Peterson, R.T., 1980, A Field Guide to the Birds, 4th ed., Houghton Mifflin Company, Boston, Mass.

Pflieger, W.L., 1975, The Fishes of Missouri, Missouri Department of Conservation, Jefferson City, Mo.

Terres, J.K., 1980, The Audubon Encyclopedia of North American Birds, Alfred A. Knopf, Inc., New York, N.Y.

Thomas, M., 1992, data from M. Thomas (MK-Ferguson Company, Weldon Spring, Mo.) provided to I. Hlohowskyj (Environmental Assessment and Information Sciences Division, Argonne National I aboratory, Argonne, III.), Sept. 17.

Tieger, J., 1988, letter fiom J. Tieger (Field Supervisor, U.S. Fish and Wildlife Service, Columbia Field Office, Columbia, Mo.) to I. Hlohowskyj (Environmental Assessment and Information Sciences Division, Argonne National Laboratory, Argonne, IIl.), Dec. 22. 
U.S. Department of Energy, 1984, Final Environmental Impact Statement, Remedial Actions at the Former Vitro Chemical Company Site, South Salt Lake, Sult Lake County, Utah, DOE/EIS-0099-F, July.

U.S. Department of Energy, 1991, Biological Assessment for the New Production Reactor at the Hanford Site, Richland, Wash., Jan.

U.S. Department of Energy, 1992a, Baseline Assessment for the Chemical Plant Area of the Weldon Spring Site, DOE/OR/21548-091, prepared by Argonne National Laboratory, Environmental Assessment and Information Sciences Division, Argonne, Ill., for U.S. Department of Energy, Oak Ridge Field Office, Weldon Spring Site Remedial Action Project, St. Charles, Mo., Nov.

U.S. Department of Energy, 1992b, Feasibility Study for Remedial Action at the Chemical Plant Area of the Weldon Spring Site, DOE/OR/21548-148, prepared by Environmental Assessment and Information Sciences Division, Argonne National Laboratory, Argonne, III., for U.S. Department of Energy, Oak Ridge Field Office, Weldon Spring Site Remedial Action ''rniect, St. Charles, Mo., Nov.

U.S. Department of Energy, 1992c, Remedial Investigation for the Chemical Plant Area of the Weldon Spring Site, DOE/OR/21548-074, Rev. 0, Vols. 1-II, prepared by MK-Ferguson Company and Jacobs Engineering Group, Weldon Spring, Mo., for U.S. Department of Energy, Oak Ridge Field Office, Weldon Spring Site Remedial Action Project, Weldon Spring, Mo., Nov.

U.S. Department of Energy, 1992d, Addendum to the Remedial Investigation for the Chemical Plant Area of the Weldon Spring Site, DOE/OR/21548-272, Rev. 0, prepared by MK-Ferguson Company and Jacobs Engineering Group, St. Charles, Mo., for U.S. Department of Energy, Oak Ridge Field Office, Weldon Spring Site Remedial Action Project, St. Charles, Mo., Nov.

U.S. Environmental Protection Agency, 1988, Guidance for Conducting Remedial Investigations and Feasibility Studies under CERCLA, Interim Final, EPA/540/G-89/004 (OSWER Directive 9355.3-01), Office of Emergency and Remedial Response, Washington, D.C., Oct.

U.S. Environmental Protection Agency, 1990, National Oil and Hazardous Substances Pollution Contingency Plan; Final Rule (40) CFR Part 3(0)), Federal Register, 55(35):6154-6176, Feb. 21.

U.S. Fish and Wildlife Service, 1988, Regional News, Endangered Species Technical Bulletin, $X I I I(4): 2$ and 7.

U.S. Fish and Wildlife Service, 1989, Nutional Wetlands Inventory Map, Wentzville Quadrangle, U.S. Department of the Interior, National Wetlands Inventory, St. Petersburg, Fla.

U.S. Fish and Wildlife Service, 1991a, Endangered and Threatened Wildlife und Plants (50) CFR 17.11 and 17.12), July 15. 
U.S. Fish and Wildlife Service, 1991b, Endangered and Threatened Wildlife and Plants; Animal Candidate Review for Listing as Endangered or Threatened Species, Proposed Rule (5) CFR Part 17), Federal Register, 56(225):58804, Nov. 21.

Waste Technologies Group, Inc., 1992, Final Report, Stabilization/Solidification Testing of Raffinate Pit Sludges and Nitroaromatic Soils, prepared by Waste Technologies Group, Inc., Atlanta, Ga., for MK-Ferguson Company, Weldon Spring Site Remedial Action Project, St. Charles, Mo., May 8.

Weiss, S., 1992, facsimile transmittal from S. Weiss (Westinghouse Hanford Co., Richland, Wash.) to I. Hohowskyj (Environmental Assessment and Information Sciences Division, Argonne National Laboratory, Argonne, III.), Oct. 22. 

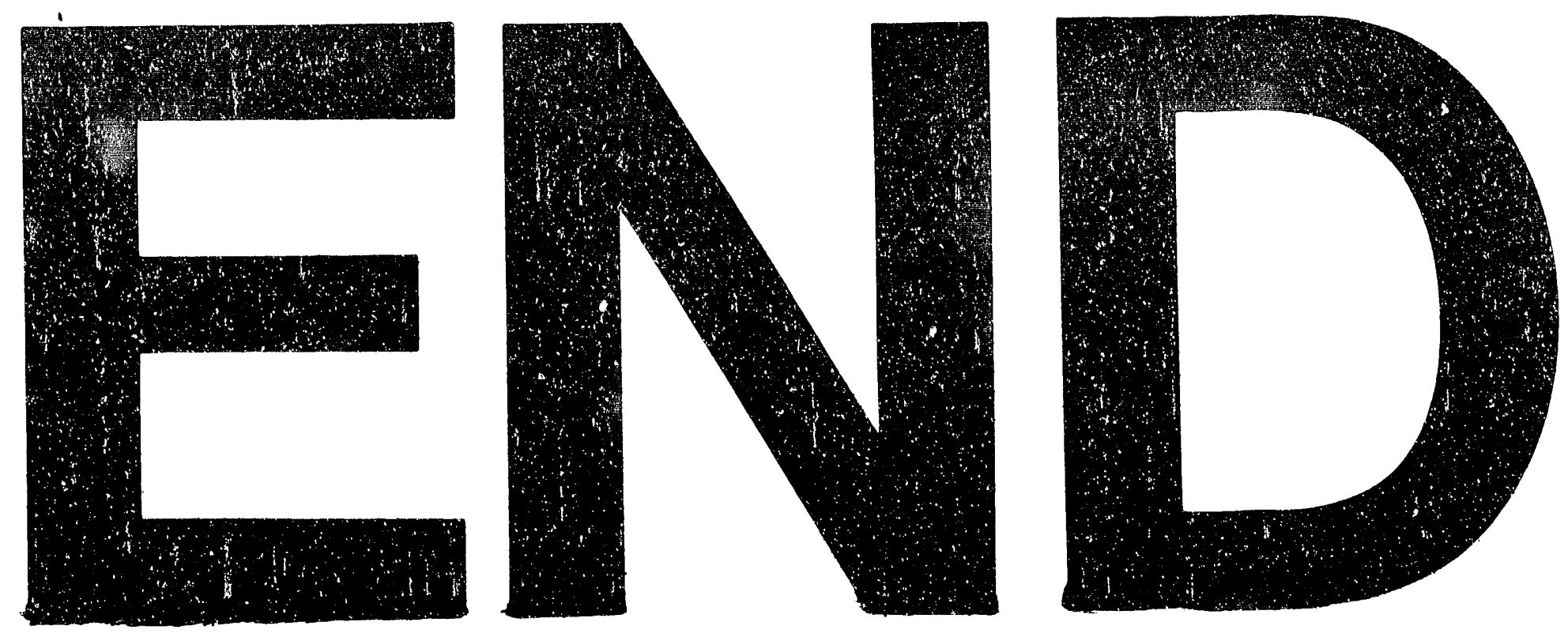

'ب
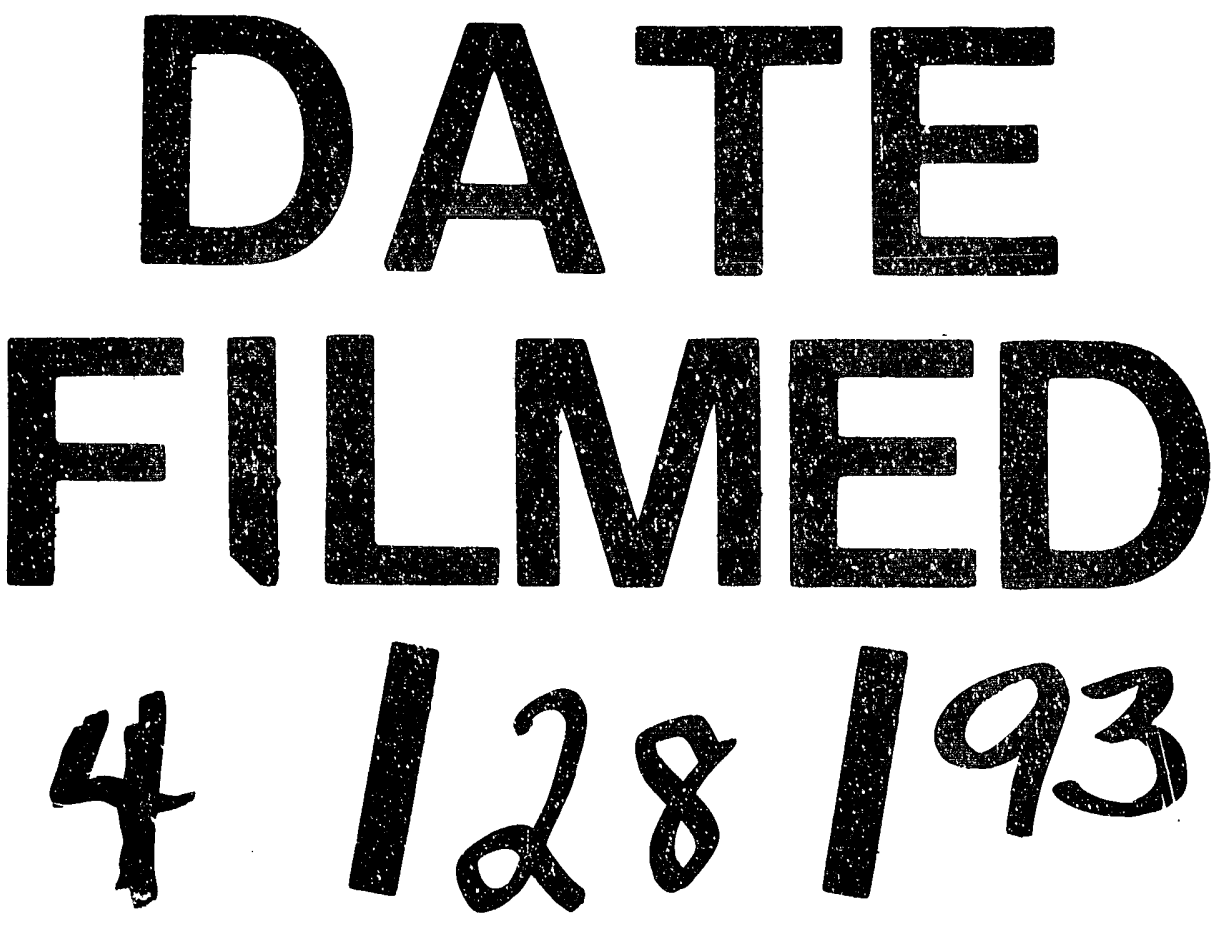
